\title{
Edible Leafy Plants from Mexico as Sources of Antioxidant Compounds, and Their Nutritional, Nutraceutical and Antimicrobial Potential: A Review
}

\author{
Lourdes Mateos-Maces ${ }^{1}$, José Luis Chávez-Servia ${ }^{2, *} *$, Araceli Minerva Vera-Guzmán ${ }^{2}{ }^{\mathbb{D}}$, \\ Elia Nora Aquino-Bolaños ${ }^{3}$, Jimena E. Alba-Jiménez ${ }^{4}(\mathbb{D}$ and \\ Bethsabe Belem Villagómez-González ${ }^{2}$ \\ 1 Recursos Genéticos y Productividad-Genética, Colegio de Posgraduados, Carr. México-Texcoco Km. 36.5, \\ Montecillo, Texcoco 56230, Mexico; lourdes.mateos@colpos.mx \\ 2 CIIDIR-Oaxaca, Instituto Politécnico Nacional, Ciudad de México 07738, Mexico; avera@ipn.mx (A.M.V.-G.); \\ bvillagonez1600@alumno.ipn.mx (B.B.V.-G.) \\ 3 Centro de Investigación y Desarrollo de Alimentos, Universidad Veracruzana, Xalapa-Enríquez 1090, \\ Mexico; eliaquino@uv.mx \\ 4 CONACyT-Centro de Investigación y Desarrollo de Alimentos, Universidad Veracruzana, \\ Xalapa-Enríquez 1090, Mexico; jimalba@uv.mx \\ * Correspondence: jchavezs@ipn.mx
}

Received: 15 May 2020; Accepted: 13 June 2020; Published: 20 June 2020

\begin{abstract}
A review of indigenous Mexican plants with edible stems and leaves and their nutritional and nutraceutical potential was conducted, complemented by the authors' experiences. In Mexico, more than 250 species with edible stems, leaves, vines and flowers, known as "quelites," are collected or are cultivated and consumed. The assessment of the quelite composition depends on the chemical characteristics of the compounds being evaluated; the protein quality is a direct function of the amino acid content, which is evaluated by high-performance liquid chromatography (HPLC), and the contribution of minerals is evaluated by atomic absorption spectrometry, inductively coupled plasma-optical emission spectrometry (ICP-OES) or ICP mass spectrometry. The total contents of phenols, flavonoids, carotenoids, saponins and other general compounds have been analyzed using UV-vis spectrophotometry and by HPLC. For the determination of specific compounds such as phenolic compounds, flavonoids, organic acids and other profiles, it is recommended to use HPLC-DAD, UHPLC-DAD, UFLC-PDA or gas chromatography-mass spectrometry. The current biochemical analysis and biological evaluations were performed to understand the mechanisms of action that lead to decreased glucose levels and lipid peroxidation, increased hypoglycemic and antitumor activity, immune system improvement, increased antibacterial and antifungal activity and, in some cases, anti-Helicobacter pylori activity.
\end{abstract}

Keywords: indigenous knowledge; bioactive compounds; malnutrition; wild edible plants; dietary diversification

\section{Introduction}

Diets in all countries are essentially based on the production of a few cultivated species-corn, rice, wheat, potato, soybean, barley, various vegetable species, yuca, beet, tomato, banana and watermelon-and nearly 160 edible species with worldwide distribution have been recorded [1]. The predominance of a few cultivated species and products in the market leads to increased dietary homogeneity; there is a direct relationship between a high diversity of natural edible products in supply systems and dietary variety, which influences the nutritional quality of the diet and affects the health 
status of individuals. Additional issues include transitions in dietary patterns, the Westernization of diets and the increased consumption of foods of animal origin, foods containing refined flour and sugar or foods with high caloric value. A low-quality diet increases the risk of undernutrition and malnutrition, and this is exacerbated by socioeconomic, cultural and political factors such as income, food education, an increased supply of edible products without nutritional value, inequity, access to food, cultural identity and gender issues [2-4].

Dietary diversification is an essential principle for optimal human nutrition. For example, a diet that is diverse in sources of minerals, amino acids and proteins, vitamins, vegetable fat, calories and bioactive compounds with high antioxidant activity helps prevent chronic diseases and improves the health and immune system of individuals. In Mexico and Latin America, people of poor families have increased their consumption of ultraprocessed products, animal fat, proteins, sugar, high-calorie foods and products with little or no nutritional value, which leads to problems of malnutrition, overweight, obesity, diabetes and other chronic degenerative diseases [3,5], and these problems are more severe in urban, suburban and marginalized or low-income areas.

In all indigenous communities, there is local knowledge about the consumption of wild and semicultivated plants that complement or compose the basic diet of people, and in situations where it is difficult to access to basic products, these plants are used to combat hunger and malnutrition within the community [6]. In general, edible native plants are wild or semidomesticated but are easily accessible; local knowledge is needed for their identification and for information concerning their cultural heritage with respect to their use as food. Furthermore, their diversity depends on the biogeographic region of distribution. In this context, there are three crucial elements for defining the use of plants for food: local knowledge, plant diversity and plant composition as a function of the environment that expresses its properties. For example, in the Congo and Brazil, plants are extracted from forested areas [7,8], and they have certain nutritional values based on the species and origin. A similar situation occurs with respect to Mediterranean plants [9], with plants having particular flavors distributed throughout the Iberian Peninsula [10]. Other cases involve plants in cultivated areas of the Mesoamerican region, specifically in milpa systems [11] and home gardens [12,13].

Edible native plants, both wild and those tolerated in crop fields, are sources of macro- and micronutrients such as vitamins, minerals, fiber, amino acids and proteins, carbohydrates and functional compounds in sufficient quantities to satisfy the daily requirements of an individual [14-16]. However, despite the importance of these native vegetables for all indigenous communities, there are few studies on the nutritional and nutraceutical composition of their edible leaves, stems, flowers, roots and tubers. For example, in Mexico, approximately 2168 different food species, not solely quelites, have been recorded based on ethnobotanical studies of useful plants, but the proximate analysis and protein, amino acid and bioactive compound profiles are available for fewer than 30 species, including those of the genera Amaranthus, Begonia, Chenopodium, Cyclanthera, Erythrina, Sechium, Cucurbita, Xanthosoma, Phaseolus and Phytolacca [17]. Species with edible stems and leaves stand out in their supply of micronutrients to alleviate nutritional deficiencies, mainly in children and pregnant women, and prevent chronic diseases [18,19]. Guil-Guerrero [20] noted that, in addition to documenting the nutritional composition of wild plants, their cytotoxic, allergic or poisonous effects should be studied. In the present work, a review was conducted of the edible native species of Mexico called 'quelites'; special emphasis was placed on those with edible leaves, vines and stems, and on their nutritional composition, bioactive compound content, ability to alleviate dietary deficiencies, nutraceutical potential and antimicrobial use. Additionally, the authors' field and laboratory experiences with edible native plants used in the indigenous communities of Mexico were included.

\section{Biogeographic Context of Plants and Comparative Analysis}

This review focused on two basic principles of inclusion: (1) only the references on plants native and those originating in Mexico were included based on the reports of Villaseñor [21], excluding plants with origins in other countries [22], such as quinua from South America and many other cases, 
and (2) we focused on species with edible young stems, leaves, vines and flowers, which excluded species with edible grains or cereals, tubers, fruits and strawberries. In this biogeographic context, the review included all species named in Mexico as 'quelites' based on ethnobotanical reports and the authors' documentation, which is explained in more detail in the next section.

An initial goal was to determine which Mexican quelites have been analyzed for their composition, and afterward, a special emphasis was also given to the phenolic compounds from green tissues and their antioxidant activity and potential effects on human health and antimicrobial action based on in vivo and in vitro evaluations. Therefore, based on an average number of 250 Mexican quelite species [17], we found that no more than $15 \%$ of the expected total had been subjects of composition and biological activity studies, as discussed below. In addition, the bioactive compounds are products of secondary metabolism (i.e., phenylpropanoid pathway), where the type and concentration of compounds are influenced by species, genotype or cultivar, environment in which the plant developed and species/genotype-environment interactions [23]. Consequently, comparisons of the composition and/or extracts of species are not feasible due to differences among species and raw materials because all evaluated species do not originate from the same growing conditions and are not separable from genetic or genotypic environmental effects. Therefore, we predominantly analyzed the experimental and biological effects as a function of the major compounds reported instead of comparing their compositions among species, but we did consider the chemical characteristics of the extracted compounds.

\section{Diversity and Consumption of Quelites from Mexico}

In Mexico, the word "quelite," derived from the indigenous Nahuatl word "quilitl," is used to group all herbaceous, woody, creeping or shrubby plants with or without edible flowers, leaves, vines and stems, regardless of whether they are unprocessed (fresh) or processed. These plants represent a fraction of the biodiversity of plants used as food, which includes grains, fruits, seeds, oilseeds, roots, tubers and other edible structures. Based on floristic and ethnobotanical lists, Mapes and Basurto [17] estimated that in Mexico, there are more than 250 wild, semicultivated and cultivated quelite species that grow in natural areas, are tolerated in crop fields, are on the borders of plots or home gardens or are cultivated for marketing. The main families include the Leguminosae, Asteraceae, Begoniaceae, Brassicaceae, Solanaceae, Piperaceae, Euphorbiaceae, Cucurbitaceae, Amaranthaceae, Convolvulaceae, Chenopodiaceae and 30 others (Table 1). However, fewer than 10 crop species occupy 12.6 million hectares cultivated in Mexico, constituting $85 \%$ of the total cultivated area [1] and reflecting a global pattern that is repeated from country to country. This indicates that the diversity of food species is underutilized, a fact that influences dietary diversity and nutritional quality with consequences such as nutritional deficiencies that arise because the main crops are essentially grain and cereal crops, not vegetable crops. Increasing dietary diversity with the consumption of a greater number of species has been proposed as an effective and sustainable strategy to eradicate micronutrient deficiency problems and malnutrition problems associated with overweight and diabetes due to the high intake of fats and ultraprocessed foods and to facilitate access to food, all through the increased consumption of quelites or traditional local vegetables [6,11,24].

Species of quelites or plants with edible stems, leaves, vines and flowers are distributed globally, and in Mexico, they are found in natural and disturbed environments, grazing areas, all agrosystems, parks and protected natural areas. They are widely used in the territories of indigenous communities, where a great number of previously unknown edible species have been recognized, although their consumption is diffused locally or regionally, and they are sold only in local and regional markets where residents are likely to recognize and use them. There is a direct relationship between local knowledge of species and how they are consumed, even when there are cultural transformations of consumption and environmental or anthropogenic changes that shift the distribution or cause the extinction of species [25]. Species of quelites are distributed in practically all eco- and agrosystems in Mexico, from the northern desert [26] to the humid tropical regions of the southern portion [27]. This fact is evident in different ethnobotanical studies that list edible plant species, although the number of species varies from site to site depending on the biogeographic context, the ecosystem, 
the agrosystem and the specific objectives of each study; however, together, such studies indicate the number of food species that can be considered to be members of the group of quelites. For example, in Candelaria Loxicha, Oaxaca, 73 food species were recorded, and only 16 were quelites in Sierra Norte de Puebla, 94 species were recorded, and 80 were quelites. Consequently, the number of recorded quelite species continues to increase (Table 2). Collective findings indicate that there are more than 250 species of quelites, as indicated by Mapes and Basurto [17], and this number can be estimated by considering the presence of three or four species per genus, multiplied by 84 genera, as listed in Table 1.

Table 1. List of plant genera with flowers, stems or leaves frequently consumed in Mexico.

\begin{tabular}{|c|c|c|c|}
\hline Plant Genera & Plant Genera & Plant Genera & Plant Genera \\
\hline Agave spp. & Cucurbita spp. & Lilaeopsis spp. & Portulaca spp. \\
\hline Amaranthus spp. & Cyclanthera spp. & Lippia spp. & Quercus spp. \\
\hline Anoda spp. & Dhalia spp. & Lobelia spp. & Rauwolfia spp. \\
\hline Arthrostema spp. & Diastatea spp. & Lycianthes spp. & Rumex spp. \\
\hline Arbutus spp. & Diphysa spp. & Microsechium spp. & Sechium spp. \\
\hline Attalea spp. & Disocactus spp. & Mimulus spp. & Senecio spp. \\
\hline Bacharis spp. & Dysphania spp. & Mosntera spp. & Sicyos spp. \\
\hline Begonia spp. & Erblichia spp. & Opuntia spp. & Singonium spp. \\
\hline Berula spp. & Erygium spp. & Orbignya spp. & Smilax spp. \\
\hline Bidens spp. & Erythrina spp. & Oxalis spp. & Solanum spp. \\
\hline Brassica spp. & Eupatorium spp. & Ouratea spp. & Sonchus spp. \\
\hline Calindrinia spp & Galinsoga spp. & Peperomia spp. & Spergula spp. \\
\hline Cestrum spp. & Hydrocotyle spp. & Persea spp. & Stellaria spp. \\
\hline Cichorium spp. & Hylocereus spp. & Petroselinum spp. & Suaeda spp. \\
\hline Chamaedorea spp. & Ipomea spp. & Phacelia spp. & Taraxacum spp. \\
\hline Chenopodium spp. & Jaltomata spp. & Phaseolus spp. & Tauschia spp. \\
\hline Claytonia spp. & Lantana spp. & Phytolacca spp. & Tinantia spp. \\
\hline Cnidoscolus spp. & Lepidium spp. & Pilea spp. & Tridax spp. \\
\hline Cotula spp. & Leucaena spp. & Piper spp. & Urtica spp. \\
\hline Crysophila spp. & Lycianthes spp & Poeppigia spp. & Xanthosoma spp. \\
\hline Crotalaria spp. & Lilaea spp. & Porophyllum spp. & Yucca spp. \\
\hline
\end{tabular}

Source: Field notes complemented with Aguilar-Støen et al. [12], Balcázar-Quiñones et al. [13] and Mapes and Basurto [17].

Table 2. A brief list of ethnobotany studies on edible native plants in different regions from Mexico.

\begin{tabular}{lcc}
\hline \multicolumn{1}{c}{ Region, Municipalities or States of Mexico } & Food Species & Ref. \\
\hline Isidro Fabela, Estado de México and Mariano Escobedo, Veracruz & $12\left(11^{1}\right)$ & {$[28]$} \\
Candelaria Loxicha, Oaxaca & $73(16)$ & {$[12]$} \\
Amatenango del Valle, Chiapas & $13(11)$ & {$[29]$} \\
Lacanja Chansayab, Chiapas & $26(5)$ & {$[27]$} \\
Sierra Norte de Puebla & $64(80)$ & {$[30]$} \\
San Pedro Arriba, Temoaya, Estado de México & $69(49)$ & {$[13]$} \\
Ixhuapan, Meyacapan, Veracruz & $138(\mathrm{~ns})$ & {$[31]$} \\
Santa María Ixcatlán, Oaxaca & $83(\mathrm{~ns})$ & {$[32]$} \\
Rayones, Nuevo León & $28(\mathrm{~ns})$ & {$[33]$} \\
San Lucas Huajotitlán y Buenavista de Juárez, Chietla, Puebla & $61(\mathrm{~ns})$ & {$[35]$} \\
59 communities of Chiapas & $131(\mathrm{~ns})$ & {$[36]$} \\
Tilzopotla, Puente de Ixtla, Morelos & {$[37]$} \\
San Agustín Loxicha, Candelaría Loxicha and Pluma Hidalgo, Oaxaca &
\end{tabular}

${ }^{1}$ Species number with edible stems, leaves and/or flowers and ns $=$ not specified.

\section{Composition of Edible Stems, Leaves and Flowers of Quelites from Mexico}

In all indigenous and rural communities in different countries, knowledge about the consumption of wild or recently domesticated plants is among the strategies for survival and adaptation to environmental conditions. In this and other studies, efforts have been made to assess traditional local and indigenous diets through the documentation of the use of food plants with local or regional distribution, which are unknown at the national and international levels; these evaluations are based on the composition of the edible portion and its contribution to human health [7,38,39]. An additional value of traditional diets is the contribution of foods that have a variety of flavors, colors, aromas and 
forms of preparation with a low number of additional inputs; for example, traditional foods are often consumed directly in fresh form or with minimal processing.

\subsection{Nutritional Composition}

Species of quelites with edible leaves, flowers, vines and stems contribute a significant amount of carbohydrates, fats, dietary fiber, protein, vitamins and minerals to the diet. For example, in the genera Amaranthus, Chenopodium, Begonia, Crotalaria, Anoda, Cyclanthera, Calandrinia, Porophyllum, Taraxacum, Tinantia, Xanthosoma, Lippia, Piper, Peperomia and Galinsoga, the protein content varies from 2.7 to $44.2 \%$, the fiber content reaches $22.7 \%$, the ash content reaches $13.0 \%$ and the carbohydrate content reaches $56.8 \%$ (dry weight), with large variations within each genus and species [40-54]. These characteristics make the proximate composition of quelites comparable to that of conventional leafy vegetables.

In the present review, it was determined that protein quality is a function of essential amino acids in reference to the quelite species listed in Table 1. For example, when studying Amaranthus hybridus, Akubugwo et al. [55] discovered relevant concentrations of histidine, alanine, arginine, aspartic acid, glutamic acid, glycine, proline, serine, isoleucine, leucine, lysine, methionine, cysteine, phenylalanine, tyrosine, threonine and valine. Bressani [56] quantified different contents of valine, threonine, isoleucine, leucine, lysine, histidine and arginine in Crotalaria longirostrata. In these two cases, A. hybridus and C. longirostrata have six essential amino acids in concentrations that vary from 1.76 to $6.7 \mathrm{~g} / 100 \mathrm{~g}$ protein and contain histidine, which is indispensable for children and pregnant women. From a rural community perspective, these edible plants are locally available, inexpensive protein and amino acid sources. However, it is necessary to not solely evaluate plants from Mexico [7,15].

One of the greatest contributions of edible leafy plants or quelites is their content of minerals such as $\mathrm{K}, \mathrm{Ca}, \mathrm{Mg}, \mathrm{P}, \mathrm{S}, \mathrm{Fe}, \mathrm{Zn}, \mathrm{Mn}, \mathrm{Na}, \mathrm{B}, \mathrm{Mo}, \mathrm{Cu}$ and $\mathrm{Co}$, which varies widely among the genera Amaranthus, Anoda, Begonia, Calandrinia, Chenopodium, Crotalaria, Cucurbita, Cyclanthera, Erythrina, Lippia, Phaseolus, Peperomia, Piper, Porophyllum, Portulaca, Suaeda, Tinantia, Tridax and Xanthosoma [32,40,43,49,53,54,57-59]. In the genera Amaranthus, Begonia, Cyclanthera, Cucurbita (leaves), Phytolacca, Piper, Porophyllum, Solanum and Tinantia, important amounts of vitamins $A, B_{1}, B_{2}, B_{3}, B_{6}, E$ and $C$, as well as niacin, have been determined $[35,39,43,50,55]$. In addition, the leaves and stems of some edible plants are a source of pigments; for example, carotenoids are present in Amaranthus cruentus, Chenopodium berlandieri and Portulaca oleracea [41,54], and betalains are present in Amaranthus hypochondriacus [48].

\subsection{Antioxidant Compounds}

The leaves, stems and flowers of some edible plants are a source of natural antioxidant phytochemicals, such as phenolic compounds, flavonoids, alkaloids, saponins, carotenoids, betalains and chlorophyll (Table 3). For example, carotenoids are present in Begonia nelumbiifolia [60], and betalains are present in Amaranthus spp. Significant amounts of flavonoid and phenolic compound contents have been recorded in the genera Amaranthus, Begonia, Brassica, Chenopodium, Phaseolus, Piper, Porophyllum and Portulaca. Regarding specific flavonoids, Begonia nelumbiifolia contains quercetin, rutin and kaempferol [60], and myricetin has been identified in Brassica rapa [61]. In addition, Santiago-Saenz et al. [54] detected the presence of rutin, phloridzin, myricetin, quercetin and phloretin in Chenopodium berlandieri, and Velázquez-Ibarra et al. [51] and Santiago-Saenz et al. [54] detected a high variation in myricetin and apigenin in Portulaca oleracea. Regarding specific phenolic compounds, Seong et al. [61] detected the presence of caffeic acid, sinapic acid, $p$-coumaric acid and ferulic acid in Brassica rapa, and Santiago-Saenz et al. [54] detected the presence of caffeic, gallic, chlorogenic, vanillic, $p$-hydroxybenzoic, ferulic and syringic acids in Chenopodium berlandieri. In addition, in Phaseolus coccineus, Szymańska and Kruk [62] determined the presence of alpha- and gamma-tocopherols; in Portulaca oleracea, Santiago-Saenz et al. [54] identified caffeic, gallic, vanillic and ferulic acids. Additionally, tannins have been identified in Portulaca oleracea [51], Chenopodium nuttalliae [43,44,53], Brassica rapa [61], Amaranthus hybridus [55] and Amaranthus cruentus [41]. In addition, Barrón-Yánez et al. [43] detected the presence of saponins in Chenopodium nuttalliae, 
and Ibarra-Estrada et al. [63] identified erisovine and erisodine alkaloids in Erythrina Americana [64]. In Begonia nelumbiifolia, Villa-Ruano et al. [60] evaluated the content of oxalic acid and ascorbic acid, and in Chenopodium berlandieri, Lazo-Vélez et al. [65] identified triterpenoid saponins. These results indicate that there are different bioactive compounds that have not yet been evaluated and identified in various edible leafy plant species preserved by indigenous communities.

The antioxidant activity is commonly assayed by different methods, such as 1,1-diphenyl-2-picrylh ydrazyl (DPPH) radical scavenging, ferric reducing antioxidant power (FRAP), oxygen radical absorbance capacity (ORAC), 2,2-azinobis 3-ethylbenzothiazoline-6-sulfonic acid radical (ABTS) scavenging and $N, N$-dimethyl- $p$-phenylenediamine radical (DMPD) scavenging applied to study this group of quelites (Table 3); the phytochemical compounds present have been shown to have the ability to sequester reactive species and/or stop molecular oxidation during oxidative stress [66,67].

Phenolic compounds, flavonoids, betacyanins and chlorophyll are some of the compounds responsible for antioxidant activity in quelites. Román-Cortés et al. [53] detected a significant positive correlation between total phenolic compounds and flavonoids with respect to antioxidant activity determined by ABTS, DPPH and DPMD methods. Using FRAP and ORAC, Li et al. [48] also found correlations between total phenolic compounds, total flavonoids and total betalains, and Sarker et al. [68] found correlations between total phenolic compounds, flavonoids, carotenoids, betacyanin, betaxanthin, betalain and chlorophyll via DPPH and ABTS. Although these tests estimate the groups of molecules present, they provide information on their activity or the synergism between them. However, the antioxidant activity in these types of plant can vary according to the genus [53], species [49] and accession within each species [68-70]. The results can also differ in each part of the plant; for example, in Amaranthus spp., antioxidant activity (FRAP and ORAC) is different in the seeds, stems, leaves, flowers and shoots, with the highest values found in leaves and the lowest in the seeds [48].

It should be noted that the most consumed quelites in rural populations, such as 'huauzontles' (Chenopodium nuttalliae), 'quelites' (Chenopodium album), 'quintoniles' (Amaranthus hypochondriacus), 'romeritos' (Suaeda calceoliformis) and 'verdolagas' (Portulaca oleracea), have higher antioxidant activity (ABTS, DMPD and DPPH) than commercial leafy vegetables such as lettuce (Lactuca sativa) and spinach (Spinacia oleracea) [53]. Similarly, in accessions of Gynandropsis gynandra, Cnidoscolus aconitifolius, Solanum scabrum and Crotalaria, antioxidant activity (ORAC) was higher than in these vegetables [49,71]. Additionally, Jiménez-Aguilar [69] determined that Amaranthus spp. antioxidant activity (ORAC) was higher than that in those vegetable species [49,71]. This suggests that quelites may be an important source of potential antioxidant phytochemical compounds with health effects. It is evident that by including quelites in the diet, their contribution of bioactive compounds would be transcendental in populations with greater problems of malnutrition and health caused by poor eating habits in recent times.

\subsection{Methods and Techniques for the Determination of Compounds}

Assessing the compositions of leaves, stems and flowers of quelite species preponderantly depends on the compound characteristics. For example, in the evaluation of micro- and macrominerals, it is convenient to use atomic absorption spectrophotometry (AAS), inductively coupled plasma-optical spectrometry (ICP-OES) and ICP-mass spectrometry (ICP-MS), where the last two techniques offer major capacity to detect trace elements or very low concentrations $[15,54,55,68]$. The determination of amino acid contents by high-performance liquid chromatography (HPLC) is a feasible option when the objective is to compare samples or species and protein quality. UV-vis spectrophotometry is a frequent strategy to estimate the total phenols, flavonoids, carotenoids and other compounds based on standards of reference, but when the aim is to elucidate compound profiles or specific compounds, it is pertinent to apply HPLC with diode array detection (HPLC-DAD) and mass spectrometry detection, ultrahigh-performance liquid chromatography with diode array detection (UHPLC-DAD) or gas chromatography-mass spectrometry (GC-MS), Table 4. 
Table 3. Compound involved in the secondary metabolism of quelite species and their antioxidant activity.

\begin{tabular}{|c|c|c|c|c|}
\hline Species & Plant Part & Antioxidant Compounds & Antioxidant Activity ${ }^{1}$ & Ref. \\
\hline Amaranthus cruentus & Whole plant & Total phenolics (gallic acid), total flavonoids (catechin) and tannins & & [41] \\
\hline A. hypochondriacus, A. caudatus and A. cruentus & $\begin{array}{l}\text { Leaves, stalks, flowers, } \\
\text { sprouts and seeds }\end{array}$ & $\begin{array}{l}\text { Betalain; amaranthine; iso-amaranthine; betanin; iso-betanin-gallic, } \\
\text { protocatechuic, chlorogenic, gentistic, 2,4-dihydroxybenzoic, ferulic, } \\
\text { ellagic and salicylic acids; rutin; kaempferol-3-rutinoside; } \\
\text { and quercetin }\end{array}$ & FRAP and ORAC & [48] \\
\hline A. hybridus & Leaves & $\begin{array}{l}\text { Alkaloids, flavonoids, saponins, tannins, phenols, hydrocyanic acid } \\
\text { and phytic acid }\end{array}$ & & [55] \\
\hline A. spinosus and $A$. viridis & Leaves & $\begin{array}{l}\text { Chlorophyll, total carotenoids, } \beta \text {-cyanin and } \beta \text {-xanthin content, } \\
\beta \text {-carotene, vitamin } C \text {, total polyphenols and total flavonoids }\end{array}$ & DPPH and ABTS & {$[68]$} \\
\hline A. acanthochiton, A. deflexus and A. viridis & Leaves & Vitamin C, total phenolics (gallic acid), flavonoids (catechin) & ORAC & [69] \\
\hline $\begin{array}{l}\text { A. hybridus, Chenopodium berlandieri and } \\
\text { Portulaca oleracea }\end{array}$ & Leaves & $\begin{array}{l}\text { Chlorophyll; carotenoids; ferulic, chlorogenic, caffeic, gallic, } \\
\text { chlorogenic, vanillic, } p \text {-hydroxybenzoic, } p \text {-coumaric and syringic } \\
\text { acids; rutin; phloridzin; myricetin; quercetin; naringenin; phloretin; } \\
\text { galangin; apigenin }\end{array}$ & DPPH, ABTS and FRAP & [54] \\
\hline $\begin{array}{l}\text { Portulaca oleracea, Chenopodium spp., Amaranthus spp., } \\
\text { Chenopodium spp. and Suaeda spp. }\end{array}$ & Leaves & $\begin{array}{l}\text { Total phenolics (gallic acid), total flavonoids (quercetin) and } \\
\text { condensed tannins }\end{array}$ & DPPH, ABTS and DMPD & [53] \\
\hline $\begin{array}{l}\text { Cnidoscolus aconitifolius, Solanum scabrum, Crotalaria } \\
\text { longirostrata and Gynandropsis gynandra }\end{array}$ & Leaves & Vitamin C, total phenolics (gallic acid) and total flavonoids (catechin) & ORAC & [49] \\
\hline Begonia nelumbiifolia & Stalks and leaves & $\begin{array}{l}\beta \text {-Carotene, lutein, } \beta \text {-cryptoxanthin, } \alpha \text {-carotene, quercetin, rutin } \\
\text { and kaempferol }\end{array}$ & $\mathrm{DPPH}$ & [60] \\
\hline $\begin{array}{l}\text { Brassica rapa } \\
\text { Phaseolus coccineous }\end{array}$ & $\begin{array}{l}\text { Leaves } \\
\text { Young leaves }\end{array}$ & $\begin{array}{l}\text { Caffeic acid, sinapic acid, } p \text {-coumaric acid, ferulic acid and myricetin } \\
\alpha \text {-Tocopherols, } \gamma \text {-tocopherols and } \delta \text { - tocopherols }\end{array}$ & DPPH, FRAP, TEAC and ORAC & $\begin{array}{l}{[61]} \\
{[62]}\end{array}$ \\
\hline Portulaca oleracea & Whole plants & $\begin{array}{l}\text { Total phenolics (gallic acid), total flavonoids (rutin) and } \\
\text { total carotenoids }\end{array}$ & DPPH and FRAP & [70] \\
\hline Piper auritum & Leaves & $\begin{array}{l}\beta \text {-Pinene, } \alpha \text {-terpinene, trans- } \beta \text {-ocimene, terpinolene, safrole, } \\
\beta \text {-caryophyllene, germacrene } D \text {, trans-nerolidol and phytol }\end{array}$ & ABTS & [52] \\
\hline
\end{tabular}

${ }^{1}$ DPPH, 1,1-Diphenyl-2-picrylhydrazyl; FRAP, ferric reducing antioxidant power; ORAC, oxygen radical absorbance capacity; TEAC, Trolox equivalent antioxidant capacity; DMPD,

$N, N$-dimethyl- $p$-phenylenediamine. 
Table 4. A list of methods and techniques used for determinate the composition in quelite species.

\begin{tabular}{|c|c|c|c|}
\hline Compounds & Methods of Determination/Identification & Species Evaluated & Ref. \\
\hline \multirow[t]{2}{*}{ Minerals } & Atomic absorption spectrophotometry (AAS) & $\begin{array}{l}\text { A. hybridus, A. viridis. A. spinosus, C. chaymansa, } \\
\text { C. berlandieri, P. oleracea }\end{array}$ & {$[15,54,55,68,70]$} \\
\hline & $\begin{array}{l}\text { Inductively coupled plasma-optical emission spectrometry } \\
\text { (ICP-OES) and ICP-mass spectrometry (ICP-MS) }\end{array}$ & $\begin{array}{l}\text { P. oleracea, C. chaymansa, C. berlandieri, } \\
\text { C. acnotifolius, C. longirostrata. }\end{array}$ & {$[49,64,72]$} \\
\hline Amino acids & High-performance liquid chromatography (HPLC) & 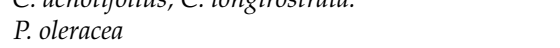 & [72] \\
\hline $\begin{array}{l}\text { Vitamin A, C, } \alpha \text {-tocopherol, phenols, } \\
\text { carotenoids, flavonoids, betalains, } \\
\text { betacyanins, saponins }\end{array}$ & UV-vis spectrophotometry and HPLC-DAD/HPLC-MS & $\begin{array}{l}\text { P. oleracea, C. chaymansa, B. nelumbiifolia, } \\
\text { A. cruentus, A. hypochondriacus, A. caudatus, } \\
\text { A. viridis, A. spinosus, A. hybridus, C. berlandieri, } \\
\text { C. lingirostrata, C. nuttallie }\end{array}$ & {$[15,47-49,54,60,65,68,70,72,73]$} \\
\hline Phenolic compounds and profiles & $\begin{array}{l}\text { High-performance liquid chromatography with diode array } \\
\text { detection (HPLC-DAD), ultrahigh-performance liquid } \\
\text { chromatography with diode array detection (UHPLC-DAD) } \\
\text { and gas chromatography-mass spectrometry (GC-MS) }\end{array}$ & $\begin{array}{l}\text { C. ambrosioides, C. chaymansa, A. viridis, } \\
\text { A. cruentus, A. hypochondriacus, A. caudatus }\end{array}$ & {$[47,55,73,74]$} \\
\hline Organic acids & $\begin{array}{l}\text { Ultrafast liquid chromatography coupled to a photodiode array } \\
\text { detector (UFLC-PDA) and HPLC-DAD }\end{array}$ & C. ambrosioides, B. nelumbiifolia & {$[60,75]$} \\
\hline
\end{tabular}




\section{Antioxidant Compounds and Health}

Quelites or edible leafy plants have the potential to prevent and reduce the incidence of diseases caused by oxidative stress, such as metabolic syndrome, diabetes, cancer and gastrointestinal and neurological diseases, among other diet-associated disorders [60,70,76]. Experiments have been performed to evaluate the nutraceutical potential of edible leafy plants or quelites.

\subsection{Diabetes}

Juárez-Reyes et al. [76] found that extracts of Anoda cristata leaves decrease glucose levels in hyperglycemic mice and that they have a positive effect on serum glucose, triglycerides and the uric acid content in mice with fructose-induced metabolic syndrome. The authors noted that the hypoglycemic effect and antioxidant activity of $A$. cristata are associated with acacetin and diosmetin. Thus, consumption of $A$. cristata is suggested to help reduce the risk of type 2 diabetes and cardiovascular diseases.

Aqueous extracts of leaves of Portulaca oleracea generate a decrease in serum glucose levels in diabetic mice. This effect is attributed to the increased insulin secretion in $\beta$-cells resulting from the improvement in the transport of glucose to peripheral tissues. Consequently, P. oleracea extract helps to prevent necrosis and atrophy of pancreatic tissue and increases blood circulation by opening blood vessels. Additionally, it reduces the levels of the proinflammatory cytokines TNF- $\alpha$ and IL-6, which are related to the pathogenesis of insulin resistance $[77,78]$.

Methanolic extracts of Cnidoscolus chayamansa at concentrations of $70 \mathrm{mg} / \mathrm{kg}$ reduce the blood glucose concentration in mice with induced diabetes. The extracts act by stimulating functional pancreatic $\beta$-cells [79]. In this sense, aqueous extracts $(2 \% w / v)$ of $C$. chayamansa show hypoglycemic activity in diabetic mice by inhibiting glucose absorption or improving sensitivity to insulin [73]. The effects of these extracts are related to the content of quercetin and catechin and are proposed to act as inhibitors of glucose absorption in intestinal cells [80]. Additionally, C. chayamansa extracts inhibited the growth of mutagenic cancer cells by $24 \%$ and $39 \%$ compared to that of sodium azide $\left(\mathrm{NaN}_{3}\right)$ and 4-nitro-O-phenylenediamine (4-N-O-P) controls, respectively [75]; furthermore, the same extracts decreased low-density lipoproteins [LDLs] by $32 \%$ and triglycerides by $50 \%$ and consequently decreased hyperlipidemia [76].

\subsection{Cancer}

Barros et al. [75] pointed out that plants/young shoots of Chenopodium ambrosioides have high antioxidant activity attributed to their bioactive molecules, and the experimental results of antitumor activity by the use of infusion and methanolic extracts inhibited growth by $50 \%\left(\mathrm{GI}_{50}\right)$ in human cell lines (MCF-7, NCI-H460, HCT-15, HeLa, HepG2) at concentrations from 287.4 to $>400 \mu \mathrm{g} / \mathrm{mL}$ ). The consumption of Cnidoscolus aconitifolius induces a protective effect against premalignant lesions (cancer) of the colon in rats by inhibiting cell proliferation and inflammation of colon lesions through a reduction in $\beta$-catenin and cyclooxygenase 2 (COX-2) activity [81]. Additionally, extracts of polysaccharides from Portulaca oleracea reduce sarcoma 180 transplanted into mice and have a mitogenic or comitogenic effects on splenocytes in mice with sarcomas by stimulating the proliferation of spleen lymphocytes, an immune response that improves immunity. In another experiment, it was demonstrated that these plant extracts can activate $\mathrm{T}$ cells to exert an immunomodulatory effect on tumors in mice [82]. In this respect, Amaranthus cruentus extracts inhibit tumor growth in colon cancer via cytotoxic activity related to the content of rutin, an antioxidant molecule that induces apoptosis and cell cycle arrest $[83,84]$.

Jia-liang et al. [85] indicated that Chenopodium ambrosioides has anticancer activity based on the evaluation of an essential oil that inhibits the proliferation of breast cancer cells (MCF-7) and can be cytotoxic depending on the concentration and time of exposure. For these reasons, a minimum $\mathrm{IC}_{50}$ of $24 \mathrm{~h}$ is proposed. Essential oil of C. ambrosioides causes morphological alterations, membrane blebbing 
and chromatin condensation, which are typical characteristics of the apoptotic process, and induces DNA fragmentation in cancer cells, reducing the survival of malignant cells [86]. C. ambrosioides leaf extracts induce macrophage activation and phagocytic activity, increase cell recruitment and/or proliferation in secondary lymphoid organs (spleen, lymph node), induce positive immunomodulation in the body and induce nitric oxide (NO) production; together, these effects improve the immune system [87]. In addition, the evaluation of methanolic extracts of the inflorescences and leaves of C. ambrosioides determined that the extracts' antitumor effects against colon, cervical and hepatocellular cancer in vitro is attributable to the content of flavonoids and phenolic acids, which are bioactive molecules with antioxidant capacity that counteract oxidative stress [75].

\subsection{Obesity and Gastrointestinal Disorder}

The ethanolic extracts of Polygonum aviculare L. have an anti-obesity effect in mice with induced obesity and fed high-fat diets. These extracts reduce the increase in body weight, increase in adipose tissue, adipocyte size and expression of lipogenic genes (PPAR $\gamma$, SREBP-1c, aP2 and FAS) and consequently decrease serum levels of triglycerides, leptin and malondialdehyde (MDA) [88]. The variation in MDA levels indicates a decrease in lipid peroxidation, which could be related to the antioxidant properties of quercetin and other phenolic compounds present in the extracts [88,89].

Ethanolic extracts of Amaranthus spinosus inhibit gastrointestinal propulsive movements in mice via the $\alpha 2$-adrenergic receptor pathway. A. spinosus has antidiarrheal activity due to its inhibitory effect on the propulsion and secretion of fluids through the mechanism of $\alpha 2$-adrenoceptors and its antiulcerogenic activity against acute gastric ulcers, by which it reduces the peroxidation of lipids generated by alterations caused by ulcers. These effects are attributed in part to the presence of phenolics, tannins and flavonoids in A. spinosus and their ability to eliminate free radicals [90].

Anoda cristata, Cnidoscolus aconitifolius and Crotalaria pumila have counteract effects on Helicobacter pylori [91], a gram-negative bacterium responsible for triggering chronic gastritis, peptic ulcer diseases and gastric cancer [92]. Dichloromethane extracts of these three species exert an inhibitory effect on bacterial growth, with minimum inhibitory concentrations (MICs) of 62.5, 125 and $250 \mu \mathrm{g} / \mathrm{mL}$, respectively, and inhibit approximately $50 \%$ of the adhesion of the bacterium to human adenocarcinoma gastric cells (AGS). The inhibitory activity against $H$. pylori is related to acacetin and diosmetin. Consequently, the extracts have potential for use in prophylactic treatments to eradicate H. pylori [91].

In addition to the direct consumption of quelites, the ability of fermentation processes to improve the functional activity of bioactive compounds has also been evaluated; for example, the effects of lactic acid fermentation of the juice of Portulaca oleracea with Lactobacillus kunkeei B7 have been examined [93,94]. In this case, fermentation improved both the juice's antioxidant capacity and the bioavailability of vitamin $B_{2}$ and increased the levels of phenolic compounds, $\gamma$-amino butyric acid and $\alpha$-linalool. The results showed that the fermented juice of P. oleracea decreases the production of intracellular ROS, preserves the integrity of monolayers of Caco-2 cells with inflammatory stimuli and limits the production of proinflammatory mediators such as prostaglandin E2 via cyclooxygenase enzymes and nitric oxide via iNOS, IL-8 and MCP-1. As with dietary fiber, the fermented juice of P. oleracea has the ability to preserve the integrity of the intestinal barrier, thus counteracting intestinal inflammation and oxidative damage [95].

\subsection{Other Disorders}

The ethanolic extracts of C. ambrosioides have an anti-arthritic effect according to the results of an experiment with mice with arthritis induced by type II collagen antibody applied at a dose of $5 \mathrm{mg} / \mathrm{kg}$. The results indicate that these extracts reduce the percentage of neutrophils and macrophages and the number of bone marrow cells and increase the number of lymphocytes and cells in inguinal lymph nodes. This treatment reduces the serum concentration of proinflammatory cytokines (IL-6 and TNF- $\alpha$ ), which cause the destruction of joints; consequently, the extract of $C$. ambrosioides protects joints by delaying bone density loss and cartilage and bone deformities [95]. C. ambrosioides has also been 
studied as an antifertility or contraceptive agent. Ain et al. [96] found that methanolic leaf extracts exert antifertility effects in adult male Sprague-Dawley rats with partial sterility induced by altering the spermatogenic cycle via oxidative stress and hormone imbalance. Although additional studies are needed, these findings imply the possible use of these extracts in reproductive mechanisms, without adverse phytotoxic effects. Additionally, aqueous extracts of $C$. ambrosioides have hypotensive properties and are partially associated with cardiac effects [97], and the methanolic extracts of C. ambrosioides induce an endothelium-dependent vasodilator effect by stimulating muscarinic receptors, which are involved in the opening of potassium $(\mathrm{K}+\mathrm{Ca}$ ) channels; these effects are attributed to kaempferol, quercetin and associated compounds [98].

Studies of neurodegenerative disorders indicate that P. oleracea extracts have anti-apoptotic and antioxidant effects in rats with brain damage induced by rotenone, a neurotoxin. Moneim et al. [99] assessed the extracts of P. oleracea $(1.5 \mathrm{~mL} / \mathrm{kg})$ administered to Wistar albino rats with induced brain injury with rotenone $(12 \mathrm{mg} / \mathrm{kg})$ and Parkinson-like degeneration, and they found a significant decrease in apoptotic cells in the striatum. The results are explained by immunohistochemical detection, which indicated that P. oleracea treatment increased the expression of B-cell lymphoma-2 (Bcl-2) and decreased the levels of nuclear factor kappa B (NF- $\mathrm{KB}$ ) as a consequence of high synthesis of ROS and a reduction in thiobarbituric acid reactive substances, nitrite/nitrate and lactate dehydrogenase. Nevertheless, cultivated and wild forms of P. oleracea should be assessed in more detail, because this species has other compounds not considered in the approach, such as $\alpha$-tocopherols and omega- 3 acids (e.g., alpha-linoleic acid), among others [72].

The leaves and young stems of quelites have functional compounds such as phenolic acids, flavonoids (isoquercitrin, nicotiflorin, rutin, 4-hydroxybenzoic acid, syringic acid, vanillic acid), ascorbic acid, betanin, amaranthine, iso-amarathine, betacyanins and other compounds recorded previously, whose current initiatives are evaluated by extracts or infusions of quelites, assumed to be a complex of compounds, to assess their beneficial effect in preventing metabolic syndrome [83,84], cancer, rheumatoid arthritis [95], chronic inflammatory disease, systemic joint disorders leading to joint damage and structural bone damage $[100,101]$. Furthermore, they have prophylactic potential against brain damage and neurodegenerative diseases related to oxidative and gastrointestinal stress $[90,99]$.

\section{Antibacterial and Antifungal Activity of Quelite Extracts}

In relation to the antifungal effects of edible leafy plants, it was experimentally demonstrated that the extracts, leaves and stems of Amaranthus retroflexus have antifungal effects on five fungal strains: Penicillium verrucosum var. verrucosum (NBIMCC 2003 NRRL F-143), P. expansum, Fusarium graminearum (NBIMCC 2294 IMI 155426), Aspergillus ochraceus (NBIMCC 2002 IM-BAS) and A. niger [102]; all of these fungi produce different mycotoxins that affect human health. Galinsoga parviflora Cav. has antibacterial and antifungal effects against Bacillus subtilis, Pseudomonas aeruginosa, Escherichia coli, Aspergillus niger and Candida albicans [103], and the compounds identified as probable inhibitors include caffeoyl derivatives, isoquercitrin, quercimeritrin and quercetagetin [104]. Portulaca oleracea has antibacterial, antifungal and antiviral activities against gram-negative strains such as Escherichia coli, Pseudomonas aeruginosa and Neisseria gonorrhoeae, and gram-positive strains such as Staphylococcus aureus, Bacillus subtilis and Streptococcus faecalis, as well as antifungal activity against Candida albicans [105]; additionally, P. oleracea has protective effects against dermatophytes of the genus Trichophyton [106] and displays antiherpes properties against simplex virus type 2 [107].

Crotalaria longirostrata has antibacterial effects against Escherichia coli, Citrobacter freundii and Staphylococcus epidermidis and antifungal effects against Fusarium oxysporum A. comiteca, Fusarium oxysporum A. tequilana and Fusarium solani A. comiteca. The antifungal activity of C. longirostrata is attributed to phenolic compounds, alkaloids, essential oils and glycosides [108]. Suaeda nigra shows inhibitory effects on gram-positive strains (Bacillus cereus ATCC11778, B. subtilis ATCC6633, Staphylococcus aureus ATCC29737 and Corynebacterium rubrum ATCC14898) and gram-negative bacteria (Escherichia coli NCIM2931, Pseudomonas aeruginosa ATCC9027, Salmonella typhimurium 
ATCC23564 and Klebsiella pneumonia NCIM2719) and has antifungal effects against Candida albicans ATCC2091, Cryptococcus neoformans ATCC34664, Candida glabrata NCIM3448 and Candida apicola NCIM3367 [109]. The dichloromethane extract of Porophyllum ruderale has antiparasitic activity against both promastigote and axenic amastigote forms of Leishmania amazonensis (leishmaniasis), with is the causal agent of a disease transmitted by mosquitoes [110]. The ethyl acetate extracts of Dysphania ambrosioides and Chenopodium ambrosioides (at concentrations ranging from 4.29 to $34.37 \mathrm{mg} / \mathrm{mL}$ ) have inhibitory effects against Staphylococcus aureus, Pseudomonas aeruginosa, Enterococcus faecalis, Paenibacillus apiarius and P. thiaminolyticus, and their chloroform extracts have inhibitory effects against Mycobacterium tuberculosis, M. smegmatis and M. avium (with an MIC ranging from 156.25 to $625.0 \mu \mathrm{g} / \mathrm{mL})$ attributed to the presence of rutin $(12.5 \pm 0.20 \mathrm{mg} / \mathrm{g})$, ethyl acetate $(16.5 \pm 0.37 \mathrm{mg} / \mathrm{g})$, and $\mathrm{n}$-butanol $(8.85 \pm 0.11 \mathrm{mg} / \mathrm{g})$ as well as both quercetin and chrysin in the chloroform fractions (1.95 \pm 0.04 and $1.04 \pm 0.01 \mathrm{mg} / \mathrm{g}$, respectively) [74]. In Cnidoscolus aconitifolius, different compounds such as alkaloids, tannins, phlobatannins, saponins, flavonoids, cardiac glycosides, steroids and terpenoids have been identified that have antibacterial effects against Staphylococcus aureus, Pseudomonas aeruginosa, Klebsiella pneumoniae, Escherichia coli and Bacillus subtilis and antifungal effects against Aspergillus tamarii and Aspergillus niger [111,112].

Eryngium foetidum has antibacterial effects against Bacillus megaterium (MTCC 8510), B. subtilis (MTCC 441), B. flexus (MTCC 7024), Staphylococcus aureus (MTCC 96), Pseudomonas oleovorans (MTCC 617), P. aeruginosa, Klebsiella pneumoniae (MTCC 7028), Salmonella enterica (MTCC 1164) and Escherichia coli (MTCC 723) and antifungal effects against the fungus Candida albicans; these effects are attributed to different bioactive compounds, such as glycosides, flavonoids, phenols, saponins, tannins, anthocyanins, sterols, triterpenoids and anthraquinones [113,114]. E. foetidum has antimicrobial effects against six clinical strains of Helicobacter pylori, as evidenced by in vitro and in vivo assays [115].

Erythrina americana has antifungal effects against Alternaria solani, Botrytis cinerea, Fusarium oxysporum, Monilinia fructicola, Penicillium spp. and Trichoderma harzianum [63]. Similarly, Cestrum nocturnum has antifungal activity against Aspergillus fumigatus, A. versicolor, A. ochraceus, A. niger, Trichoderma viride, Penicillium funiculosum, P. ochrochloron, P. verrucosum var. cyclopium, Botrytis cinerea, Colletotrichum capsici, Fusarium oxysporum, F. solani, Phytophthora capsici, Rhizoctonia solani and Sclerotinia sclerotiorum, fungi that causes diseases in crop plants. Additionally, C. nocturnum has antibacterial activity against Enterobacter cloacae (human isolate), Escherichia coli, Klebsiella pneumonia, Proteus vulgaris, Pseudomonas aeruginosa, Salmonella paratyphi A, S. paratyphi B, S. typhimurium, Shigella flexneri, Bacillus cereus (clinical isolate), Listeria monocytogenes, Micrococcus flavus and Staphylococcus aureus; these effects are attributed to different compounds, such as carbohydrates and/or glycosides, tannins, condensed tannins, hydrolysable tannins, alkaloids and/or nitrogenous bases, flavonoids, sterols and/or triterpenes, saponins and coumarins [109].

Begonia maculata, B. soli-mutata, B. goegoensis, B. foliosa, hybrid Begonia x erythrophylla, B. thiemei, B. peltata, B. heracleifolia, B. dregei and B. mexicana have antibacterial effects against Escherichia coli (ATCC 25922), Staphylococcus aureus, Klebsiella pneumoniae, Pseudomonas aeruginosa and Citrobacter freundii; Escherichia coli is specifically inhibited by extracts of Begonia maculata leaves, and Citrobacter freundii is inhibited by extracts of Begonia thiemei and B. foliosa $[116,117]$. The different effects are an indicator of the different chemical compositions of the extracts or the different reactions of the pathogenic bacteria.

The extracts of the edible leaves of Persea americana are capable of inhibiting the growth of Streptococcus pyogenes, Proteus mirabilis, Klebsiella pneumoniae, Staphylococcus aureus (NCIB 8588), Klebsiella pneumoniae (NCIB 418) and Pseudomonas aeruginosa (NCIB 950), but this inhibitory effect was not observed against Salmonella typhi, Escherichia coli, E. coli (NCIB 86) or Bacillus subtilis (NCIB 3610) [118].

Edible plants have potential use in agriculture and livestock. Phytolacca dodecandra has natural fungicidal activity against chocolate spot caused by Botrytis fabae, a leaf disease of fava bean (Vicia faba L.) [119], and it has a bioinsecticidal effect against the larvae of ticks (Rhipicephalus 
appendiculatus), organisms that transmit diseases to cattle and cause severe losses of livestock [120]. P. dodecandra has antibacterial activity against Staphylococcus aureus ATCC 25923, Escherichia coli ATCC 8739 and Pseudomonas aeruginosa ATCC 9027 [121]. P. dodecandra contains various secondary metabolites, such as polyphenols, flavonoids, tannins, saponins, alkaloids, leucoanthocyanins, anthocyanins, steroids and triterpenoids, compounds to which antifungal and antibacterial properties are attributed $[120,121]$. Phytolacca americana has potential effects on periodontal inflammatory diseases and on caries caused by Porphyromonas gingivalis and Streptococcus mutans and has potential effects against Escherichia coli, and its effects are attributed to high concentrations of kaempferol, quercetin, quercetin 3-glucoside, isoquercitrin and ferulic acid [122]. Phytolacca tetramera has antifungal effects against Colletotrichum gloeosporioides (Penz.) Sacc., a fungus that causes losses in the production of agricultural, forestry and ornamental crop species [123].

Rumex dentatus, R. tingitanus, R. vesicarius, R. acetosella, R. acetosa, R. alpinus, R. aquaticus, R. conglomeratus, R. crispus, R. hydrolapathum, R. obtusifolius subsp. obtusifolius, R. obtusifolius subsp. subalpinus, R. patientia, R. pulcher, R. scutatus, R. stenophyllus and R. thyrsiflorus have antibacterial and antifungal activities against Shigella flexneri, Pseudomonas aeruginosa, Salmonella typhimurium, Staphylococcus epidermidis, S. aureus, methicillin-resistant S. aureus (MRSA), Bacillus subtilis catarrhalis, Streptococcus pyogenes, S. pneumoniae, S. agalactiae, Pseudomonas aeruginosa, Escherichia coli and Klebsiella pneumoniae. These plants also have a phytopathogenic effect against bacteria that cause losses in agricultural production, such as Agrobacterium tumefaciens C58, Agrobacterium tumefaciens B6, Aspergillus niger CTM 10099 and Fusarium graminearum (ISPAVE 271), and on fungi such as F. oxysporum (CTM10402), F. culmorum $21 \mathrm{w}$, Alternaria alternata (CTM 10230), Aspergillus versicolor, A. flavus, Acremonium spp., Penicillium dimorphosporum, Candida albicans, C. krusei and C. parapsilosis [124-127].

Sechium edule has antibacterial effects against gram-positive bacteria (Enterococcus faecalis, Staphylococcus aureus, coagulase-negative staphylococci, S. pyogenes, S. agalactiae, S. aureus ATCC 29213 and Enterococcus faecalis ATCC 29212) [128]. Similarly, Solanum torvum has an antibacterial effect against Salmonella typhi [129], and Solanum trilobatum inhibits the growth of Staphylococcus aureus, Streptococcus pyrogens, Salmonella typhi, Pseudomonas aeruginosa, Proteus vulgaris and Escherichia coli; in both cases, the effects are attributed to the presence of tannins [130].

According to Holetz et al. [131], the extracts of Cestrum nocturnum, Eryngium foetidum, Persea americana, Porophyllum ruderale, Sechium edule, and Solanum torvum are classified as having good antimicrobial activity (MIC less than $100 \mu \mathrm{g} / \mathrm{mL}$; Table 5), while the extracts of Phytolacca americana were moderate (IMC from 100 to $500 \mu \mathrm{g} / \mathrm{mL}$ ), and the extracts of Solanum trilobatum, Dysphania ambrosioides and Chenopodium ambrosioides were considered inactive (IMC greater than $1000 \mu \mathrm{g} / \mathrm{mL}$ ). Most quelites displayed higher antimicrobial activity than did the most consumed vegetables, as was the case for the following: Lactuca sativa (IMC of $2500 \mu \mathrm{g} / \mathrm{mL}$ ) against Escherichia coli (ATCC25922), Klebsiella pneumoniae CI, Staphylococcus aureus and Bacillus subtilis ATCC 6633 [132]; Spinacia oleracea (IMC of 60,000-70,000 $\mu \mathrm{g} / \mathrm{mL}$ ) against S. aureus (ATCC 29213) and E. coli OH157:H7 (ATCC 25922) [133]; and Brassica oleracea (IMC of 2500-20,000 $\mu \mathrm{g} / \mathrm{mL}$ ) against E. coli O157:H7 ATCC 35150, Salmonella typhimurium ATCC 14028, Listeria monocytogenes ATCC 35152, B. cereus ATCC 11778 and S. aureus [134]. 
Table 5. Antibacterial and antifungal activities based on extracts of quelite species.

\begin{tabular}{|c|c|c|c|c|c|}
\hline Quelite Species & $\begin{array}{c}\text { Extract }{ }^{1} \\
\text { (Plant Part) }\end{array}$ & Identified Compounds ${ }^{2}$ & Microorganisms & $\operatorname{MIC}^{3}(\mu \mathrm{g} / \mathrm{mL})$ & Ref. \\
\hline Amaranthus retroflexus & EE and ME (whole plants) & NE & $\begin{array}{l}\text { Penicillium verrucosum var. verrucosum (NBIMCC } 2003 \text { NRRL F-143), P. expansum, Fusarium } \\
\text { graminearum (NBIMCC } 2294 \text { IMI 155426) and Aspergillus ochraceus (NBIMCC } 2002 \text { IM-BAS) } \\
\text { and A. niger }\end{array}$ & 125,000 & [101] \\
\hline Galinsoga parviffora & EE (whole plants) & $\begin{array}{l}\text { Caffeoyl derivatives, isoquercitrin, quercimeritrin and } \\
\text { quercetagetin }\end{array}$ & $\begin{array}{l}\text { Bacillus subtilis (6633), Pseudomonas aeruginosa (27853), Escherichia coli (10538), Aspergillus } \\
\text { niger (16404) and Candida albicans (10231) }\end{array}$ & 100,000 & [102] \\
\hline Portulaca oleracea & ME (whole plants) & Lupeol, $\beta$-sitosterol and daucosterol & $\begin{array}{l}\text { Escherichia coli, Pseudomonas aeruginosa, Neisseria gonorrhea, Staphylococcus aureus, Bacillus } \\
\text { subtilis, and Streptococcus faecalis and Candida albicans }\end{array}$ & 1000 & [104] \\
\hline Crotalaria longirostrata & $\begin{array}{l}\text { PF, EAF, AF, DMF, EEF } \\
\text { and SDW (leaves) }\end{array}$ & $\begin{array}{l}\text { Phenolic compounds, alkaloids, essential oils and } \\
\text { glycosides }\end{array}$ & $\begin{array}{l}\text { Escherichia coli (ITTG-1879), Citrobacter freundii (Cf-ITTG) and Staphylococcus epidermidis } \\
\text { (ITG- } 850 \text { ). } \\
\text { Fusarium oxysporum A. Comiteca (FoC-ITTG), Fusarium oxysporum A. tequilana (FoT-ITTG) } \\
\text { and Fusarium solani A. comiteca (FsC-ITTG). }\end{array}$ & 200,000 & [107] \\
\hline Suaeda nigra & $\begin{array}{l}\text { PEE, EAE, } \mathrm{ACE}, \mathrm{ME} \text { and } \\
\mathrm{AE} \text { (leaves) }\end{array}$ & Cardiac glycosides & $\begin{array}{l}\text { Bacillus cereus (ATCC11778), Staphylococcus aureus (ATCC29737), Corynebacterium rubrum } \\
\text { (ATCC14898), Escherichia coli (NCIM2931), Pseudomonas aeruginosa (ATCC9027), Salmonella } \\
\text { typhimurium (ATCC23564), and Klebsiella pneumonia (NCIM2719) } \\
\text { Candida albicans (ATCC2091), Cryptococcus neoformans (ATCC34664), Candida glabrata } \\
\text { (NCIM3448) and Candida apicola (NCIM3367) }\end{array}$ & 20 & [108] \\
\hline Porophyllum ruderale & DE (leaves) & $\begin{array}{l}\text { Thiophene derivatives: } \\
\text { 5-methyl-2,2':5, } \\
5^{\prime} \text {-methyl-[5-terthiophene and } \\
5-\text {-acetoxy-1-butynyl)]-2,2'-bisthiophene }\end{array}$ & Leishmania amazonensis (WHOM/BR/75/JOSEFA) & $60.3-77.7$ & [109] \\
\hline $\begin{array}{l}\text { Dysphania ambrosioides and } \\
\text { Chenopodium ambrosioides }\end{array}$ & $\begin{array}{l}\mathrm{EE}, \mathrm{CF}, \mathrm{EAF} \text { and } \\
\mathrm{BF} \text { (leaves) }\end{array}$ & Rutin, quercetin and chrysin & $\begin{array}{l}\text { Staphylococcus aureus (ATCC 25923), Pseudomonas aeruginosa (ATCC 340), Enterococcus } \\
\text { faecalis (ATCC 29212), Paenibacillus apiaries, } P \text {. thiaminolyticus, } \\
\text { Mycobacterium tuberculosis (ATCC 25618), M. smegmatis (ATCC 700084) and M. avium } \\
\text { (LR541CDC) }\end{array}$ & $4300-68,800$ & [110] \\
\hline \multirow[t]{2}{*}{ Cnidoscolus aconitifolius } & $\begin{array}{l}\text { EE (roots, leaves, } \\
\text { and stems) }\end{array}$ & $\begin{array}{l}\text { Steroids, tannins, alkaloids, cardiac glycosides, } \\
\text { terpenoids and saponins }\end{array}$ & Klebsiella oxytoca, Escherichia coli, Proteus species, Bacillus subtilis and Pseudomonas aeruginosa & 20,000 & [111] \\
\hline & ME (leaves) & $\begin{array}{l}\text { Alkaloids, tannins, saponin, flavonoids and cardiac } \\
\text { glycoside }\end{array}$ & $\begin{array}{l}\text { Bacteria: Staphylococcus aureus, Pseudomonas aeruginosa, Klebsiella pneumoniae and } \\
\text { Escherichia coli } \\
\text { Fungi: Aspergillus tamarii and Aspergillus niger }\end{array}$ & $31,250-500,000$ & [112] \\
\hline \multirow[t]{3}{*}{ Eryngium foetidum } & $\mathrm{EE}, \mathrm{ME}$ and $\mathrm{AE}$ (leaves) & Flavonoids, phenols, saponins and tannins & $\begin{array}{l}\text { Bacillus megaterium (MTCC } 851010), \text { Bacillus subtilis (MTCC 441), Bacillus flexus (MTCC 7024), } \\
\text { Staphylococcus aureus (MTCC 96), Pseudomonas oleovorans (MTCC 617), Klebsiella pneumoniae } \\
\text { (MTCC 7028), Salmonella enteric (MTCC 1164) and Escherichia coli (MTCC 723) }\end{array}$ & 25 & [113] \\
\hline & $\begin{array}{l}\text { PEE, CE, EAE, ME and } \\
\text { AE (leaves) }\end{array}$ & $\begin{array}{l}\text { Anthocyanins, sterols, triterpenoids and } \\
\text { anthraquinones }\end{array}$ & $\begin{array}{l}\text { (a) Escherichia coli, Pseudomonas aeruginosa, Bacillus subtilis and Staphylococcus aureus. } \\
\text { (b) Candida albicans }\end{array}$ & $\begin{array}{l}\text { (a) } 3.12-200 \\
\text { (b) } 1.56-12.5\end{array}$ & [114] \\
\hline & ME and AE (leaves) & $\begin{array}{l}\text { Alkaloids, phenols, flavonoids, anthraquinones } \\
\text { and sterols }\end{array}$ & Helicobacter pylori & 64-1024 & [115] \\
\hline \multirow[t]{3}{*}{ Cestrum nocturnum } & $\mathrm{CF}, \mathrm{EAF}$ and $\mathrm{AF}$ (leaves) & $\begin{array}{l}\text { Triterpenes, coumarins, flavonoids, tannins, saponins } \\
\text { and carbohydrates }\end{array}$ & 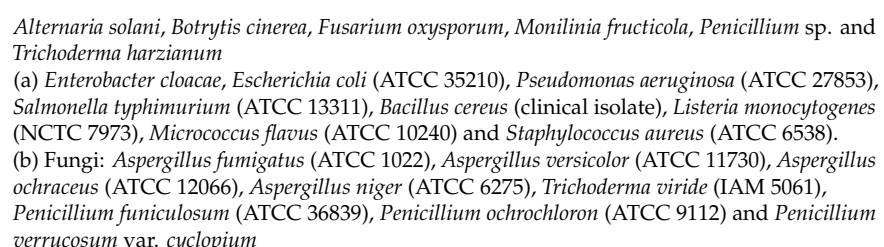 & $\begin{array}{l}\text { (a) } 0.6-3.75 \\
\text { (b) } 0.075-2.5\end{array}$ & [135] \\
\hline & $\begin{array}{l}\mathrm{EAE}, \mathrm{ME}, \mathrm{EE} \text { and } \mathrm{CE} \\
\text { (leaves and stems) }\end{array}$ & Ethyl & $\begin{array}{l}\text { Escherichia coli, Klebsiella pneumonia, Proteus vulgaris, Pseudomonas aeruginosa, Salmonella } \\
\text { paratyphi A, Salmonella paratyphi B, Shigella flexneri and Staphylococcus aureus }\end{array}$ & $\begin{array}{l}55-350 \text { and } \\
25-400\end{array}$ & [136] \\
\hline & $\begin{array}{l}\mathrm{HE}, \mathrm{CE}, \mathrm{EAE} \text { and } \\
\mathrm{ME} \text { (flower) }\end{array}$ & Acetate, ethanol, and methanol extracts & 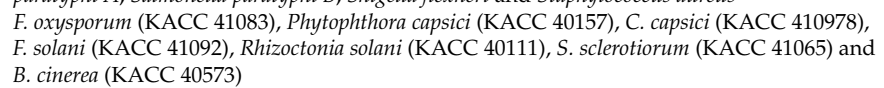 & $125-1000$ & [137] \\
\hline
\end{tabular}


Table 5. Cont.

\begin{tabular}{|c|c|c|c|c|c|}
\hline Quelite Species & $\begin{array}{c}\text { Extract }{ }^{1} \\
\text { (Plant Part) }\end{array}$ & Identified Compounds ${ }^{2}$ & Microorganisms & $\operatorname{MIC}^{3}(\mu \mathrm{g} / \mathrm{mL})$ & Ref. \\
\hline Begonia maculata & ME (leaves) & NE & $\begin{array}{l}\text { Escherichia coli (ATCC 25922), Klebsiella pneumoniae, Pseudomonas aeruginosa and } \\
\text { Staphylococcus aureus }\end{array}$ & 20,000 & [116] \\
\hline $\begin{array}{l}\text { Begonia soli-mutata, } B . \\
\text { goegoensis, } B . \text { foliosa, } B \text {. } \\
\text { erythrophylla, B. thiemei, } B . \\
\text { peltata, B. heracleifolia } B \text {. } \\
\text { dregei, B. mexicana }\end{array}$ & EE (leaves) & $\begin{array}{l}\text { Phenol, tannins, xanthoproteins, steroids, } \\
\text { phytosterols, triterpenoids, sapogenins, coumarins } \\
\text { and carbohydrates }\end{array}$ & (1) & 52,631 & [117] \\
\hline Persea americana & ME (leaves and bark) & $\begin{array}{l}\text { Saponins, tannins, phlobatannins, anthraquinone, } \\
\text { flavonoids and terpenoids }\end{array}$ & $\begin{array}{l}\text { (a) Bacillus subtilis (NCIB 3610), Staphylococcus aureus (NCIB 8588), Escherichia coli (NCIB 86), } \\
\text { Klebsiella pneumoniae (NCIB 418) and Pseudomonas aeruginosa (NCIB 950); } \\
\text { (b) Streptococcus pyogenes, Proteus mirabilis, Salmonella typhi, Klebsiella pneumoniae and } \\
\text { Escherichia coli }\end{array}$ & $\begin{array}{l}\text { (a) } 10,000-30,000 \\
\text { (b) } 3-12\end{array}$ & [118] \\
\hline Phytolacca americana & $\mathrm{ME}, \mathrm{HF}, \mathrm{CF}, \mathrm{EF}$ and $\mathrm{BF}$ & $\begin{array}{l}\text { Kaempferol, quercetin, quercetin 3-glucoside, } \\
\text { isoquercitrin and ferulic acid }\end{array}$ & $\begin{array}{l}\text { Porphyromonas gingivalis (ATCC BAA-1703), Streptococcus mutans (ATCC 700610) and } \\
\text { Escherichia coli (DH5 } \alpha \text { ) }\end{array}$ & $200-1800$ & [122] \\
\hline Sechium edule & $\begin{array}{l}\text { EE (leaves, stems } \\
\text { and fruit) }\end{array}$ & Flavonoids & $\begin{array}{l}\text { Staphylococcus aureus (ATCC 29213), Enterococcus faecalis (ATCC 29212), Streptococcus } \\
\text { agalactiae and Streptococcus pyogenes }\end{array}$ & $\begin{array}{l}4.16-16.64 \text { or } \\
8.32-16.64\end{array}$ & [128] \\
\hline Solanum torvum & $\begin{array}{l}\mathrm{CE} \text { and ME (roots, leaves } \\
\text { and stems) }\end{array}$ & Tannins & Bacillus cereus, B. subtilis, Streptococcus- $\beta$-haemolyticus, Salmonella typhi and Shigella dysenteriae & 64-128 & [129] \\
\hline
\end{tabular}

${ }^{1}$ Hexane extract (HE); chloroform extract (CE); dichloromethane extract (DE); ethyl acetate extract (EAE); ethanolic extract (EE); methanol extract (ME); aqueous extract (AE); ether extract

(ETE); petroleum ether extract (PEE); acetone extract (ACE); hexane fraction (HF); butanol fraction (BF); chloroform fraction (CF); ethyl acetate fraction (EAF); propanone fraction (PF);

ethyl acetate fraction (EAF); aqueous fraction (AF); dichloromethane fraction (DF); ethyl ether fraction (EEF); sterile distilled water $(\mathrm{SDW}){ }^{2} \mathrm{NE}=$ not evaluated; ${ }^{3} \mathrm{NR}=\mathrm{not}$ reported. 


\section{Remarks and Perspectives}

The efforts and natural and economic resources of the global production and marketing of food have focused on a few species or products, which has led to an increase in diet homogenization, with nutritional consequences and repercussions on health, generating another source of malnutrition in addition to that caused by dietary changes or transformations. Consumption patterns indicate that there is reduced consumption of vegetables [5] and that a small number of leafy plant species, which can provide high levels of nutrients, are marketed. In contrast, among indigenous communities, a large number of plant species with edible stems, leaves, vines and flowers are consumed and locally marketed. In Mexico, these plants are known as quelites or quilitl in the Nahuatl language, although this group of plants also takes other names in indigenous native languages and comprises more than 250 species. However, in Mexico, no more than 10 domesticated species occupy most of the cultivated area, corresponding to 12.6 million hectares (FAOSTAT, 2019) [1]. The inclusion of quelites in people's diet depends on documented knowledge of their nutritional and nutraceutical potential. The most studied genera with species native to Mexico are Amaranthus, Chenopodium, Begonia, Crotalaria, Anoda, Cyclanthera, Calandrinia, Porophyllum, Taraxacum, Tinantia, Xanthosoma, Lippia, Piper, Peperomia, Cucurbita and Galinsoga. Quelites provide proteins, amino acids, minerals, vitamins A, B complex, C and E and a significant amount of bioactive compounds, such as carotenoids, betalains, flavonoids, phenolic compounds and, in some cases, alkaloids and condensed tannins, among other nutrients.

In terms of nutrients, quelite species provide $2.7 \%$ to $44.2 \%$ protein based on dry weight (50 g, dietary reference intake (DRI)) and all essential amino acids except tryptophan in quantities that vary from 1.76 to $6.7 \mathrm{~g} / 100 \mathrm{~g}$ protein (DRI, $23-33 \mathrm{mg} / \mathrm{g}$ protein), including histidine, which is indispensable for children and pregnant women. Quelites also provide micro- and macroelements; for example, $100 \mathrm{~g}$ of raw Amaranthus spp. provides 13.6 and $3.8 \mathrm{mg}$ of Fe and $\mathrm{Zn}$, respectively, a sufficient amount of Fe (DRI of $10 \mathrm{mg} /$ day) and $25.3 \%$ of the total required $\mathrm{Zn}(15 \mathrm{mg} / \mathrm{day}, \mathrm{DRI})$; both of these elements are deficient in people of poor families with low income. Additionally, quelites contain $\mathrm{K}, \mathrm{Ca}, \mathrm{Mg}, \mathrm{P}, \mathrm{S}, \mathrm{Mn}$, $\mathrm{Na}, \mathrm{B}, \mathrm{Mo}, \mathrm{Cu}$ and $\mathrm{Co}$ as well as substantial amounts of vitamins $\mathrm{A}, \mathrm{B}_{1}, \mathrm{~B}_{2}, \mathrm{~B}_{3}, \mathrm{~B}_{6}$, E, and $\mathrm{C}$, plus niacin.

Members of the Amaranthus, Begonia, Brassica, Chenopodium, Phaseolus, Piper, Porophyllum and Portulaca quelite genera contain bioactive compounds such as rutin, myricetin, quercetin, catechin, amaranthine, kaempferol, epigenin, p-coumaric acid, sinapic acid, ferulic acid, gallic acid, caffeic acid, vanillic acid, ascorbic acid, oxalic acid and syringic acid, among others, which are significantly correlated with antioxidant activity, as revealed FRAP, ORAC, ABS and DMPD assays. In addition, in Chenopodium spp., Erythrina americana and Portulaca oleracea were identified as containing saponins, alkaloids and tannins, respectively.

In this review, many experimental assays provided evidence of the potential effects of quelite extracts to prevent, manage and probably control current human health problems, encouraging various theories and explanations of the effects. In this sense, the extracts of Anoda cristata, Portulaca oleracea and Cnidoscolus chayamansa present hypoglycemic activity to prevent diabetes. In addition, Chenopodium ambrosioides, Cnidoscolus aconitifolius, Portulaca oleracea and Amaranthus cruentus extracts have antitumor activity and improve the immune system. Polygonum aviculare extracts caused a decrease in lipid peroxidation, and Amaranthus spinosus extracts have antidiarrheal activity; both of these extracts have been proposed to prevent obesity. Anoda cristata, Cnidoscolus aconitifolius and Crotalaria pumila extracts displayed experimental anti-Helicobacter pylori effects.

In the antibacterial and antifungal assays and based on an MIC $<100 \mu \mathrm{g} / \mathrm{mL}$, the extracts with good antimicrobial activity were those of Suaeda nigra, Eryngium foetidum, Cestrum nocturnum and Solanum torvum against Staphylococcus, Enterococcus, Bacillus, Escherichia, Pseudomonas, Salmonella and Candida strains. In addition, Porophyllum ruderale and Persea americana extracts inhibited the growth of Leishmania amazonensis and Streptococcus strains, respectively (Table 5).

Lastly, there were a few documented cases on the use of fermented plants, plant parts or plant juices of quelite species. For example, Filannino et al. [91] and Di cagno et al. [92] found that lactic acid fermentation of the juice of Portulaca oleracea improved the bioavailability of bioactive compounds 
and enhanced functional activity. This finding opens other possibilities of the use of other vegetable species to concoct beverages.

Author Contributions: All authors contributed equally to the writing of the original draft, and J.L.C.-S. and A.M.V.-G. integrated the final version. All authors have read and agreed to the published version of the manuscript.

Funding: The authors are grateful for the financial support provided by CONACYT-Problemas Nacionales (project no. 2015-1-1119) and the Instituto Politecnico Nacional (project nos. 20201270 and 20201269).

Conflicts of Interest: The authors declare no conflict of interest.

\section{References}

1. FAOSTAT. Crops Statistics 2018; Food and Agriculture Organization of the United Nations (FAO): Rome, Italy, 2019; Available online: http://www.fao.org/faostat/en/\#data/QC (accessed on 12 May 2020).

2. Khoury, C.K.; Bjorkman, A.D.; Dempewolf, H.; Ramirez-Villegas, J.; Guarino, L.; Jarvis, A.; Rieseberg, L.H.; Struik, P.C. Increasing homogeneity in global food supplies and the implications for food security. Proc. Natl. Acad. Sci. USA 2014, 11, 4001-4006. [CrossRef]

3. Jones, A.D. Critical review of the emerging research evidence on agricultural biodiversity, diet diversity, and nutritional status in low- and middle-income countries. Nutr. Rev. 2017, 75, 769-782. [CrossRef] [PubMed]

4. Lachat, C.; Raneri, J.E.; Smith, K.W.; Kolsteren, P.; Van Damme, P.; Verzelen, K.; Penafiel, D.; Vanhover, W.; Kennedy, G.; Hunter, D.; et al. Dietary specie richness as a measure of food biodiversity and nutrition quality of diets. Proc. Natl. Acad. Sci. USA 2018, 15, 127-132. [CrossRef] [PubMed]

5. FAO; IFAD; UNICEF; WFP; WHO. The State of Food Security and Nutrition in the World 2019: Safeguarding against Economic Slowdowns and Downturns; Food and Agriculture Organization of the United Nations (FAO): Rome, Italy, 2019; p. 212.

6. Van Rensburg, W.S.J.; Venter, S.L.; Netshiluvhi, T.R.; van der Heever, E.; Vorster, H.J.; de Ronde, J.A. Role of indigenous leafy vegetables in combating hunger and malnutrition. S. Afr. J. Bot. 2004, 70, 52-59. [CrossRef]

7. Ngome, P.I.T.; Shackleton, C.; Degrande, A.; Tieguhong, J.C. Addressing constraints in promoting wild edible plants' utilization in household nutrition: Case of the Congo Basin forest area. Agric. Food Secur. 2017, 6, 20. [CrossRef]

8. Cruz, M.P.; Peroni, N.; Albuquerque, U.P. Knowledge, use and management of native wild edible plants from a seasonal dry forest (NE, Brazil). J. Ethnobiol. Ethnomed. 2013, 9, 79. [CrossRef] [PubMed]

9. Ceccanti, C.; Landi, M.; Benvenuti, S.; Pardossi, A.; Guidi, L. Mediterranean wild edible plants: Weeds or "new functional crops"? Molecules 2018, 23, 2299. [CrossRef]

10. Pardo-de-Santayana, M.; Tardío, J.; Blanco, E.; Carvalho, A.M.; Lastra, J.J.; San Miguel, E.; Morales, R. Traditional knowledge of edible plants used in the northwest of the Iberian Peninsula (Spain and Portugal): A comparative study. J. Ethnobiol. Ethnomed. 2007, 3, 27. [CrossRef]

11. Mavengahama, S.; McLachlan, M.; de Clercq, W. The role of wild vegetable species in household food security in maize based subsistence cropping systems. Food Sec. 2013, 5, 227-233. [CrossRef]

12. Aguilar-Støen, M.; Moe, S.R.; Camargo-Ricalde, S.L. Home gardens sustain crop diversity and improve farm resilience in Candelaria Loxicha, Oaxaca, Mexico. Hum. Ecol. 2009, 37, 55-77. [CrossRef]

13. Balcázar-Quiñones, A.; White-Olascoaga, L.; Chávez-Mejía, C.; Zepeda-Gómez, C. The edible tender plants species richness and traditional knowledge in the Otomí community of San Pedro Arriba, Temoaya, State of Mexico. Polibotanica 2020, 48, 219-242.

14. Ranhotra, G.S.; Gelroth, J.A.; Leinen, S.D.; Viñas, M.A.; Lorenz, K.J. Nutritional profile of some edible plants from Mexico. J. Food Comps. Anal. 1998, 11, 298-304. [CrossRef]

15. Bordoloi, M.; Bordoloi, P.K.; Dutta, P.P.; Singh, V.; Nath, S.; Nazary, B.; Bhuyan, P.D.; Rao, P.G.; Barua, I.C. Studies on some edible herbs: Antioxidant activity, phenolic content, mineral content and antifungal properties. J. Funct. Foods 2016, 23, 220-229. [CrossRef]

16. Hoidal, N.; Diaz-Gallardo, M.; Jacobsen, S.-E.; Alandia, G. Amaranth as a dual-use crop for leafy greens and seeds: Stable responses to leaf harvest across genotypes and environments. Front. Plant Sci. 2019, 10, 817. [CrossRef] 
17. Mapes, C.; Basurto, F. Biodiversity and edible plants of Mexico. In Ethnobotany of Mexico, Interactions of People and Plants in Mesoamerica; Lira, R., Casas, A., Blancas, J., Eds.; Springer Nature: New York, NY, USA, 2016; pp. 83-131.

18. Flyman, M.V.; Aflayan, A.J. The suitability of wild vegetables for alleviating human dietary deficiencies. $S$. Afr. J. Bot. 2006, 72, 492-497. [CrossRef]

19. Santiago-Sáenz, Y.O.; Hernández-Fuentes, A.D.; López-Palestina, C.U.; Garrido-Cauich, J.H.; Alatorre-Cruz, J.M.; Monroy-Torres, R. Importancia nutricional y actividad biológica de los compuestos bioactivos de quelites consumidos en México. Rev. Chil. Nutr. 2019, 46, 593-605. [CrossRef]

20. Guil-Guerrero, J.L. The safety of edible wild plants: Fuller discussion may be needed. J. Food Comps. Anal. 2014, 35, 18-20. [CrossRef]

21. Villaseñor, J.L. Checklist of the native vascular plants of Mexico. Rev. Mex. Biodivers. 2016, 87, 559-902. [CrossRef]

22. Villaseñor, J.L.; Espinosa-García, F. The alien flowering plants of Mexico. Divers. Distrib. 2004, 10, $113-123$. [CrossRef]

23. Cheynier, V.; Comte, G.; Davies, K.M.; Lattazio, V.; Martens, S. Plan phenolic: Recent advances on their biosynthesis, genetics and ecophysiology. Plant. Physiol. Biochem. 2013, 72, 1-20. [CrossRef]

24. Panafiel, D.; Lachat, C.; Espinel, R.; van Damme, P.; Kolsteren, P. A systematic review on the contribution of edible plant and animal biodiversity to human diets. EcoHealt 2011, 8, 381-399. [CrossRef] [PubMed]

25. Boege, E. El patrimonio Biocultural de los Pueblos Indígenas de México: Hacia la Conservación in situ de la Biodiversidad y Agrobiodiversidad en los Territorios Indigenas [Biocultural Heritage of the Indigenous Communities of Mexico: Forward in situ Conservation of the Biodiversity and Agrobiodiversity in the Indigenous Territory]; Instituto Nacional de Antropología e Historia, Comisión Nacional para el Desarrollo de los Pueblos Indígenas: Mexico City, Mexico, 2010; p. 342.

26. Mora-Olivo, A.; Hurtado-González, M.; Gaona-García, G.; Treviño-Carreón, J. Chochas: Las flores comestibles del desierto [Chochas: Edible flower from the desert]. CienciasUAT 2009, 4, 10-13.

27. Falkowski, T.B.; Chankin, A.; Diemon, S.A.W.; Pedian, R.W. More than just corn and calories: A comprehensive assessment of the yield and nutritional content of a traditional Lacandon Maya milpa. Food Secur. 2019, 11, 389-404. [CrossRef]

28. Varo-Rodríguez, R.D.; Ávila-Akerber, V.D.; Gheno-Heredia, Y.A. Traditional use of phytodiversity of Pinus hartwegii forests in two Mexican high mountain communities. Cladasia 2019, 41, 327-342. [CrossRef]

29. Mascorro-de Loera, R.D.; Ferguson, B.G.; Perales-Rivera, H.R.; Charbonnier, F. Herbicides in the milpa: Application strategies and their impact on weed consumption. Ecosist. Recur. Agropec. 2019, 6, 477-486.

30. Basurto-Peña, F.; Martínez-Alfaro, M.A.; Villalobos-Contreras, G. Los quelites de la Sierra Norte de Puebla, México: Inventario y formas de preparación. Bol. Soc. Bot. Mex. 1998, 62, 49-62. [CrossRef]

31. Vázquez-García, V.; Godínez-Guevara, L.; Montes-Estrada, M.; Montes-Estrada, M.; Ortíz-Gómez, A.S. The quelites of Uxhuapan, Veracruz: Availability, supply and consumption. Agrociencia 2004, 38, 445-455.

32. Rangel-Landa, S.; Casas, A.; Rivera-Lozoya, E.; Torres-García, I.; Vallejo-Ramos, M. Ixcatec ethnoecology: Plant management and biocultural heritage in Oaxaca, Mexico. J. Ethnobiol. Ethnomed. 2016, 12, 30. [CrossRef]

33. Estrada-Castillon, E.; Garza-López, M.; Villareal-Quintanilla, J.A.; Salinas-Rodríguez, M.M.; Soto-Mata, B.E.; González-Rodríguez, H.; González-Uribe, D.U.; Cantú-Silva, I.; Carrillo-Parra, A.; Cantú-Ayala, C. Ethnobotany in Rayones Nuevo Leon, Mexico. J. Ethnobiol. Ethnomed. 2014, 10, 62. [CrossRef]

34. Martínez-Pérez, A.; López, P.A.; Gil-Muñoz, A.; Cuevas-Sánchez, A. Useful and relevant wild plants identified in the Mixteca Poblana, Mexico. Act. Bot. Mex. 2012, 98, 73-98. [CrossRef]

35. Chávez-Quiñones, E.; Roldán-Toriz, J.; Sotelo-Ortiz, B.E.; Ballinas-Díaz, J.; López-Zúñiga, E.J. Plantas comestibles no convencionales de Chiapas, México [Edible plants non-conventional of Chiapas, Mexico]. Rev. Salud Pub. Nutr. 2009, 10, 2. Available online: https://www.medigraphic.com/pdfs/revsalpubnut/spn2009/spn092g.pdf (accessed on 9 May 2020).

36. Ortiz-Sánchez, A.; Monroy-Ortiz, C.; Romero-Manzanares, A.; Luna-Cavazos, M.; Catillo-España, P. Multipurpose functions of home gardens for family subsistence. Bot. Sci. 2015, 93, 791-806. [CrossRef]

37. Luna-José, A.L.; Rendón-Aguilar, B. Recursos vegetales útiles en diez comunidades de la Sierra Madre del Sur, Oaxaca, México [Plant resources useful in ten communities from the Sierra Madre del Sur, Oaxaca, Mexico]. Polibotánica 2008, 26, 193-242. 
38. Kidane, B.; van der Maesen, L.J.G.; Asfaw, Z.; Sosef, M.S.M.; van Andel, T. Wild and semi-wild leafy vegetables used by the Naale and Ari ethnic communities in southern Ethiopia. Genet. Resour. Crop Evol. 2015, 62, 221-234. [CrossRef]

39. Galvez-Mariscal, A.; Peña-Montes, C. Evaluation of the Mexican traditional diet: An interdisciplinary overview. Revista Digital Universitaria-UNAM 2015, 16, 2-17.

40. Gutierrez, D.; Mendoza, S.; Serrano, V.; Bah, M.; Pelz, R.; Balderas, P.; Leon, F. Proximate composition, mineral content, and antioxidant properties of 14 Mexican weeds used as fodder. Weed Biol. Manag. 2008, 8 , 291-296. [CrossRef]

41. Adebooye, O.C.; Vijayalakshmi, R.; Singh, V. Peroxidase activity, chlorophylls and antioxidant profile of two leaf vegetables (Solanum nigrum L. and Amaranthus cruentus L.) under six pretreatment methods before cooking. Int. J. Food Sci. Technol. 2008, 43, 173-178. [CrossRef]

42. Kalinova, J.; Dadakova, E. Rutin and total quercetin content in amaranth (Amaranthus spp.). Plant Foods Hum. Nutr. 2009, 64, 68-74. [CrossRef]

43. Barrón-Yánez, M.R.; Villanueva-Verduzco, C.; García-Mateos, M.R.; Colinas-León, M.T. Nutrient value and saponi content of huauzontle (Chenopodium nuttalliae Saff.), zucchini (Cucurbita pepo L.), canola (Brassica napus L.) and amaranto (Amaranthus leucocarpus S. Watson syn. hypochondriacus L.) sprouts. Rev. Chapingo Ser. Hort. 2009, 15, 237-243.

44. Ibarra-Alvarado, C.; Rojas, A.; Mendoza, S.; Bah, M.; Gutiérrez, D.M.; Hernández-Sandoval, L.; Martínez, M. Vasoactive and antioxidant activities of plants used in Mexican traditional medicine for the treatment of cardiovascular diseases. Pharm. Biol. 2010, 48, 732-739. [CrossRef]

45. Castro-Lara, D.; Basurto-Peña, F.; Mera-Ovando, L.M.; Bye-Boettler, R.A. Los Quelites, Tradición Milenaria en México [The Quelites, Ancient Tradition in Mexico]; Universidad Autónoma Chapingo: Texcoco, Mexico, 2011; p. 36.

46. Khan, M.A.; Humaira, I.; Haroon, K.; Mohammmad, S.; Ikhtair, K.; Rahman, I. Antimicrobial activities of the whole plant of Cestrum nocturnum against pathogenic microorganisms. Afr. J. Microbiol. Res. 2011, 5, 612-616.

47. López-Mejía, O.A.; López-Malo, A.; Palou, E. Antioxidant capacity of extracts from amaranth (Amaranthus hypochondriacus L.) seeds or leaves. Ind. Crop. Prod. 2014, 53, 55-59. [CrossRef]

48. Li, H.; Deng, Z.; Liu, R.; Zhu, H.; Draves, J.; Marcone, M.; Sun, Y.; Tsao, R. Characterization of phenolics, betacyanins and antioxidant activities of the seed, leaf, sprout, flower and stalk extracts of three Amaranthus species. J. Food Comps. Anal. 2015, 37, 75-81. [CrossRef]

49. Jiménez-Aguilar, D.M.; Grusak, M.A. Evaluation of minerals, phytochemical compounds and antioxidant activity of Mexican, Central American, and African green leafy vegetables. Plant Foods Hum. Nutr. 2015, 70, 357-364. [CrossRef] [PubMed]

50. Salome-Abarca, L.F.; Cruz-Cruz, E.; Leyva-Vasquez, A.; Damian-Nava, A.; Palemon, F.A.; Hernández-Castro, E.; Vargas-Álvarez, A.; Sánchez-Cabañas, J.N. Biochemical characterization, antioxidant and antibacterial activity of aromatic plants from Guerrero, Mexico. Weber Medic. Plant Res. 2015, 1, 239-246. Available online: https://www.weberpub.org/wmpr/wmpr_138.pdf (accessed on 5 May 2020).

51. Velázquez-Ibarra, A.M.; Covarrubias-Prieto, J.; Ramírez-Pimentel, J.G.; Aguirre-Mancilla, C.L.; de la Fuente, G.I.; Raya-Pérez, J.C. Nutritional quality of Mexican quelites (Green leafy). Ciencia Tecnol. Agrop. México 2016, 4, 1-9.

52. Conde-Hernández, L.A.; Espinosa-Victoria, J.R.; Guerrero-Beltrán, J.Á. Supercritical extraction of essential oils of Piper auritum and Porophyllum ruderale. J. Supercrit. Fluids 2017, 127, 97-102. [CrossRef]

53. Román-Cortés, N.R.; García-Mateos, R.M.; Castillo-González, A.M.; Sahagún-Castellanos, J.; Jiménez-Arellanes, M.A. Características nutricionales y nutracéuticas de hortalizas de uso ancestral en México. Rev. Fitotec. Mex. 2018, 41, 245-253. [CrossRef]

54. Santiago-Saenz, Y.O.; Hernández-Fuentes, A.D.; Monroy-Torres, R.; Cariño-Cortés, R.; Jiménez-Alvarado, R. Physicochemical, nutritional and antioxidant characterization of three vegetables (Amaranthus hybridus L., Chenopodium berlandieri L., Portulaca oleracea L.) as potential sources of phytochemicals and bioactive compounds. J. Food Meas. Charact. 2018, 12, 2855-2864. [CrossRef]

55. Akubugwo, I.E.; Obasi, N.A.; Chinyere, G.C.; Ugbogu, A.E. Nutritional and chemical value of Amaranthus hybridus L. leaves from Afikpo, Nigeria. Afr. J. Biotechnol. 2007, 6, 2833-2839. [CrossRef]

56. Bressani, R. World Need for Improved Nutrition and the Role of Vegetables and Legumes; Asian Vegetable Research and Development Center: Shanhua, Taiwan, 1983; p. 22. 
57. Nwaogu, L.A.; Ujowundu, C.O.; Mgbemena, A.I. Studies on the nutritional and phytochemical composition of Amaranthus hybridus leaves. Bio-Research 2006, 4, 28-31. [CrossRef]

58. Manzanero-Medina, G.I.; Pérez-Herrera, A.; Lustre-Sánchez, H.; Vásquez-Dávila, M.A.; Santos-Sánchez, N.F.; Sánchez-Medina, M.A. Ethnobotanical and nutritional study of quelites sold in two traditional markets of Oaxaca, Mexico. BioRxiv 2018, Article ID 453225. [CrossRef]

59. Sarker, U.; Oba, S. Nutraceuticals, antioxidant pigments, and phytochemicals in the leaves of Amaranthus spinosus and Amaranthus viridis weedy species. Sci. Rep. 2019, 9, 1-10. [CrossRef] [PubMed]

60. Villa-Ruano, N.; Pacheco-Hernández, Y.; Cruz-Durán, R.; Lozoya-Gloria, E.; Betancourt-Jiménez, M.G. Seasonal variation in phytochemicals and nutraceutical potential of Begonia nelumbiifolia consumed in Puebla, México. J. Food Sci. Technol. 2017, 54, 1484-1490. [CrossRef] [PubMed]

61. Seong, G.U.; Hwang, I.W.; Chung, S.K. Antioxidant capacities and polyphenolics of Chinese cabbage (Brassica rapa L. ssp. Pekinensis) leaves. Food Chem. 2016, 199, 612-618. [CrossRef]

62. Szymańska, R.; Kruk, J. $\gamma$-Tocopherol dominates in young leaves of runner bean (Phaseolus coccineus) under a variety of growing conditions: The possible functions of $\gamma$-tocopherol. Phytochemistry 2008, 69, 2142-2148. [CrossRef]

63. Ibarra-Estrada, E.; Téllez-Morales, R.; Soto-Hernández, M.; Martínez-Vázquez, M.; García-Mateos, R.; San San Miguel-Chávez, R. In vitro antifungal activity of erysovine. Rev. Fitotec. Mex. 2009, 32, 327-330.

64. Rambo, D.F.; Biegelmeyer, R.; Toson, N.S.; Dresch, R.R.; Moreno, P.R.H.; Henriques, A.T. The genus Erythrina L.: A review on its alkaloids, preclinical, and clinical studies. Phytother. Res. 2019, 33, 1258-1276. [CrossRef]

65. Lazo-Vélez, M.A.; Guajardo-Flores, D.; Mata-Ramírez, D.; Gutiérrez-Uribe, J.A.; Serna-Saldivar, S.O. Characterization and quantitation of triterpenoid saponins in raw and sprouted Chenopodium berlandieri spp. (Huauzontle) grains subjected to germination with or without selenium stress conditions. J. Food Sci. 2016, 81, C19-C26. [CrossRef]

66. Gülcin, I. Antioxidant activity of food constituents: An overview. Arch. Toxicol. 2012, 86, 345-391. [CrossRef]

67. Tena, N.; Martín, J.; Asuero, A.G. State of the Art of Anthocyanins: Antioxidant Activity, Sources, Bioavailability, and Therapeutic Effect in Human Health. Antioxidants 2020, 9, 451. [CrossRef]

68. Sarker, U.; Hossain, M.M.; Oba, S. Nutritional and antioxidant components and antioxidant capacity in green morph Amaranthus leafy vegetable. Sci. Rep. 2020, 10, 1-10. [CrossRef] [PubMed]

69. Jiménez-Aguilar, D.M.; Grusak, M.A. Minerals, vitamin C, phenolics, flavonoids and antioxidant activity of Amaranthus leafy vegetables. J. Food Compost. Anal. 2017, 58, 33-39. [CrossRef]

70. Alam, M.; Juraimi, A.S.; Rafii, M.Y.; Abdul, H.A.; Aslani, F.; Hasan, M.M.; Mohd, Z.M.; Uddin, M. Evaluation of antioxidant compounds, antioxidant activities, and mineral composition of 13 collected purslane (Portulaca oleracea L.) accessions. Biomed. Res. Int. 2014, Article ID 296063, 10 pages. [CrossRef]

71. Wu, X.; Beecher, G.R.; Holden, J.M.; Haytowitz, D.B.; Gebhardt, S.E.; Prior, R.L. Lipophilic and hydrophilic antioxidant capacities of common foods in the United States. J. Agric. Food Chem. 2004, 52, 4026-4037. [CrossRef] [PubMed]

72. Nemzer, B.; Al-Taher, F.; Abshiru, N. Phytochemical composition and nutritional value of different plant parts in two cultivated and wild purslane (Portulaca oleracea L.) genotypes. Food Chem. 2020, 320, Article ID 126621. [CrossRef] [PubMed]

73. Ramos-Gómez, M.; Figueroa-Pérez, M.G.; Guzmán-Maldonado, H.; Loarca-Piña, G.; Mendoza, S.; Quezada-Tristán, T.; Reynoso-Camacho, R. Phytochemical profile, antioxidant properties and hypoglycemic effect of chaya (Cnidoscolus chayamansa) in Stz-induced diabetic rats. J. Food Biochem. 2017, 41, 1-9. [CrossRef]

74. Jesus, R.S.; Piana, M.; Freitas, R.B.; Brum, T.F.; Alves, C.F.S.; Belke, B.V.; Mossmann, N.J.; Cruz, R.C.; Santos, R.C.V.; Dalmolin, T.V.; et al. In vitro antimicrobial and antimycobacterial activity and HPLC-DAD screening of phenolics from Chenopodium ambrosioides L. Braz. J. Microb. 2019, 49, 296-302. [CrossRef]

75. Barros, L.; Pereira, E.; Calhelha, R.C.; Dueñas, M.; Carvalho, A.M.; Santos-Buelga, C.; Ferreira, I.C. Bioactivity and chemical characterization in hydrophilic and lipophilic compounds of Chenopodium ambrosioides L. J. Funct. Foods 2013, 5, 1732-1740. [CrossRef]

76. Juárez-Reyes, K.; Brindis, F.; Medina-Campos, O.N.; Pedraza-Chaverri, J.; Bye, R.; Linares, E.; Mata, R. Hypoglycemic, antihyperglycemic, and antioxidant effects of the edible plant Anoda cristata. J. Ethnopharmacol. 2015, 161, 36-45. [CrossRef]

77. Ramadan, B.K.; Schaalan, M.F.; Tolba, A.M. Hypoglycemic and pancreatic protective effects of Portulaca oleracea extract in alloxan induced diabetic rats. BMC Complement. Altern. Med. 2017, 17, 37. [CrossRef] 
78. Tangvarasittichai, S.; Pongthaisong, S.; Tangvarasittichai, O. Tumor necrosis factor-A, interleukin-6, C-reactive protein levels and insulin resistance associated with type 2 diabetes in abdominal obesity women. Indian J. Clin. Biochem. 2016, 31, 68-74. [CrossRef] [PubMed]

79. Loarca-Piña, G.; Mendoza, S.; Ramos-Gómez, M.; Reynoso, R. Antioxidant, antimutagenic, and antidiabetic activities of edible leaves from Cnidoscolus chayamansa Mc. Vaugh. J. Food Sci. 2010, 75, H68-H72. [CrossRef] [PubMed]

80. Johnston, K.; Sharp, P.; Clifford, M.; Morgan, L. Dietary polyphenols decrease glucose uptake by human intestinal Caco-2 cells. FEBS Lett. 2005, 579, 1653-1657. [CrossRef] [PubMed]

81. Kuri-García, A.; Godínez-Santillán, R.I.; Mejía, C.; Ferriz-Martínez, R.A.; García-Solís, P.; Enríquez-Vázquez, A.; García-Gasca, T.; Guzmán-Maldonado, S.H.; Chávez-Servín, J.L. Preventive effect of an infusion of the aqueous extract of Chaya leaves (Cnidoscolus aconitifolius) in an aberrant crypt foci rat model induced by azoxymethane and dextran sulfate sodium. J. Med. Food 2019, 22, 851-860. [CrossRef] [PubMed]

82. Shen, H.; Tang, G.; Zeng, G.; Yang, Y.; Cai, X.; Li, D.; Liu, H.; Zhou, N. Purification and characterization of an antitumor polysaccharide from Portulaca oleracea L. Carbohydr. Polym. 2013, 93, 395-400. [CrossRef]

83. Sekar, V.; Jayshree, N. Phytochemical analysis and in vitro anticancer study of ethanolic extract of leaves of Amaranthus cruentus Linn. against colon cancer cell line (HCT-116). World J. Pharm. Pharm. Sci. 2017, 6, 1644-1658. [CrossRef]

84. Perk, A.A.; Shatynska-Mytsyk, I.; Gerçek, Y.C.; Boztaş, K.; Yazgan, M.; Fayyaz, S.; Farooqi, A.A. Rutin mediated targeting of signaling machinery in cancer cells. Cancer Cell Int. 2014, 14, 1-5. [CrossRef]

85. Jia-liang, W.; Dan-wei, M.; Ya-nan, W.; Hong, Z.; Bing, H.; Qun, L.; Zhi-yan, Z.; Jing, F. Cytotoxicity of essential oil of Chenopodium ambrosioides L. against human breast cancer MCF-7 cells. Trop. J. Pharm. Res. 2013, 12, 929-933. [CrossRef]

86. Degenhardt, R.T.; Farias, I.V.; Grassi, L.T.; Franchi, G.C., Jr.; Nowill, A.E.; Bittencourt, C.M.D.S.; Wagner, T.M.; de Souza, M.M.; Cruza, A.B.; Malheiros, A. Characterization and evaluation of the cytotoxic potential of the essential oil of Chenopodium ambrosioides. Rev. Bras. Farmacogn. 2016, 26, 56-61. [CrossRef]

87. Cruz, G.V.; Pereira, P.V.S.; Patrício, F.J.; Costa, G.C.; Sousa, S.M.; Frazao, J.B.; Aragao-Filho, W.C.; Maciel, M.C.G.; Silva, L.A.; Amaral, F.M.M.; et al. Increase of cellular recruitment, phagocytosis ability and nitric oxide production induced by hydroalcoholic extract from Chenopodium ambrosioides leaves. J. Ethnopharmacol. 2007, 111, 148-154. [CrossRef]

88. Sung, Y.Y.; Yoon, T.; Yang, W.K.; Kim, S.J.; Kim, D.S.; Kim, H.K. The antiobesity effect of Polygonum aviculare L. ethanol extract in high-fat diet-induced obese mice. Evid. Based Complement. Alternat. Med. 2013, Article ID 626397, 11 pages. [CrossRef]

89. Hsu, C.Y. Antioxidant activity of extract from Polygonum aviculare L. Biol. Res. 2006, 39, 281-288. [CrossRef] [PubMed]

90. Hussain, Z.; Amresh, G.; Singh, S.; Rao, C.V. Antidiarrheal and antiulcer activity of Amaranthus spinosus in experimental animals. Pharm. Biol. 2009, 47, 932-939. [CrossRef]

91. Gomez-Chang, E.; Uribe-Estanislao, G.V.; Martinez-Martinez, M.; Gálvez-Mariscal, A.; Romero, I. Anti-Helicobacter pylori potential of three edible plants known as Quelites in Mexico. J. Med. Food 2018, 21, 1150-1157. [CrossRef]

92. Kusters, J.G.; van Vliet, A.H.; Kuipers, E.J. Pathogenesis of Helicobacter pylori infection. Clin. Microbiol. Rev. 2006, 19, 449-490. [CrossRef]

93. Filannino, P.; Di Cagno, R.; Trani, A.; Cantatore, V.; Gambacorta, G.; Gobbetti, M. Lactic acid fermentation enriches the profile of biogenic compounds and enhances the functional features of common purslane (Portulaca oleracea L.). J. Funct. Foods 2017, 39, 175-185. [CrossRef]

94. Di Cagno, R.; Filannino, P.; Vincentini, O.; Cantatore, V.; Cavoski, I.; Gobbetti, M. Fermented Portulaca oleracea L. juice: A novel functional beverage with potential ameliorating effects on the intestinal inflammation and epithelial injury. Nutrients 2019, 11, 248. [CrossRef]

95. Pereira, W.S.; da Silva, G.P.; Vigliano, M.V.; Leal, N.R.; Pinto, F.A.; Fernandes, D.C.; Santos, S.V.M.; Martino, T.; Nascimento, J.R.; de Azevedo, A.P.S.; et al. Anti-arthritic properties of crude extract from Chenopodium ambrosioides L. leaves. J. Pharm. Pharmacol. 2018, 70, 1078-1091. [CrossRef]

96. Ain, Q.U.; David, M.; Shah, Q.; Ahmad, M.; Jahan, S. Antifertility effect of methanolic leaf extract of Chenopodium ambrosioides Hook. in male Sprague Dawley rats. Andrologia 2018, 50, e13129. [CrossRef] 
97. Assaidi, A.; Legssyer, A.; Berrichi, A.; Aziz, M.; Mekhfi, H.; Bnouham, M.; Ziyyat, A. Hypotensive property of Chenopodium ambrosioides in anesthetized normotensive rats. J. Complement. Integr. Med. 2014, 11, 1-7. [CrossRef]

98. Assaidi, A.; Dib, I.; Tits, M.; Angenot, L.; Bellahcen, S.; Bouanani, N.; Legssyer, A.; Aziz, M.; Mekhfi, H.; Bnouham, M.; et al. Chenopodium ambrosioides induces an endothelium-dependent relaxation of rat isolated aorta. J. Integr. Med. 2019, 17, 115-124. [CrossRef] [PubMed]

99. Moneim, A.E.A.; Dkhil, M.A.; Al-Quraishy, S. The potential role of Portulaca oleracea as a neuroprotective agent in rotenone-induced neurotoxicity and apoptosis in the brain of rats. Pestic. Biochem. Phys. 2013, 105, 203-212. [CrossRef]

100. Sokolove, J. Rheumatoid arthritis pathogenesis and pathophysiology. In Lung Disease in Rheumatoid Arthritis; Fischer, A., Lee., J.S., Eds.; Springer International Publishing AG: Cham, Switzerland, 2018; pp. 19-30.

101. Gibofsky, A. Overview of epidemiology, pathophysiology, and diagnosis of rheumatoid arthritis. Am. J. Manag. Care 2012, 18, 295-302.

102. Terzieva, S.; Velichkova, K.; Grozeva, N.; Valcheva, N.; Dinev, T. Antimicrobial activity of Amaranthus spp. extracts against some mycotoxigenic fungi. Bulg. J. Agric. Sci. 2019, 25, 120-123.

103. Mostafa, I.; El-Aziz, E.A.; Hafez, S.; El-Shazly, A. Chemical constituents and biological activities of Galinsoga parviflora Cav. (Asteraceae) from Egypt. Zeitschrift für Naturforschung C 2013, 68, 285-292. [CrossRef]

104. Agnieszka, B.; Stolarczyk, M.; Derwinska, M.; Kiss, A.K. Determination of antioxidant activity of extracts and fractions obtained from Galinsoga parviflora and Galinsoga quadriradiata, and a qualitative study of the most active fractions using TLC and HPLC methods. Nat. Prod. Lett. 2012, 26, 1584-1593.

105. Elkhayat, E.S.; Ibrahim, S.R.M.; Aziz, M.A. Portulene, a new diterpene from Portulaca oleracea L. J. Asian Nat. Prod. Res. 2008, 10, 1039-1043. [CrossRef]

106. Oh, K.B.; Chang, I.M.; Hwang, K.J.; Mar, W. Detection of antifungal activity in Portulaca oleracea by a single-cell bioassay system. Phytother. Res. 2000, 14, 329-332. [CrossRef]

107. Dong, C.X.; Hayashi, K.; Lee, J.B.; Hayashi, T. Characterization of structures and antiviral effects of polysaccharides from Portulaca oleracea L. Chem. Pharm. Bull. 2010, 58, 507-510. [CrossRef]

108. Miranda-Granados, J.; Chacón, C.; Ruiz-Lau, N.; Vargas-Díaz, M.E.; Zepeda, L.G.; Alvarez-Gutiérrez, P.; Meza-Gordillo, R.; Lagunas-Rivera, S. Alternative use of extracts of chipilín leaves (Crotalaria longirostrata Hook. \& Arn) as antimicrobial. Sustainability 2018, 10, 883.

109. Padalia, H.; Rathod, T.; Chanda, S. Evaluation of antimicrobial potential of different solvent extracts of some medicinal plants of semi-arid region. Asian J. Pharm. Clin. Res. 2017, 10, 295-299. [CrossRef]

110. Takahashi, H.T.; Novello, C.R.; Ueda-Nakamura, T.; Palazzo de Mello, J.C.; Nakamura, C.V. Thiophene derivatives with antileishmanial activity isolated from aerial parts of Porophyllum ruderale (Jacq.) Cass. Molecules 2011, 16, 3469-3478. [CrossRef] [PubMed]

111. Adeniran, O.I.; Olajide, O.O.; Igwemmar, N.C.; Orishadipe, A.T. Phytochemical constituents, antimicrobial and antioxidant potentials of tree spinach [Cnidoscolus aconitifolius (Miller) I.M. Johnston]. J. Med. Plants Res. 2013, 7, 1317-1322.

112. Fagbohun, E.D.; Egbebi, A.O.; Lawal, O.U. Phytochemical screening, proximate analysis and in-vitro antimicrobial activities of methanolic extract of Cnidoscolus aconitifolius leaves. Int. J. Pharm. Sci. Rev. Res. 2012, 13, 28-33.

113. Malik, T.; Kumar, P.D.; Roy, P.; Okram, A. Evaluation of Phytochemicals, Antioxidant, Antibacterial and Antidiabetic Potential of Alpinia galanga and Eryngium foetidum Plants of Manipur (India). Pharm. J. 2016, 8, 459-464. [CrossRef]

114. Lingaraju, D.P.; Sudarshana, M.S.; Mahendra, C.; Poornachandra, R.K. Phytochemical screening and antimicrobial activity of leaf extracts of Eryngium foetidum 1. (apiaceae). Indo-Amer. J. Pharm. Res. 2016, 6, 4339-4344.

115. Kouitcheu, M.L.B.; Eyoum, B.B.; Nguepi, E. In vitro and in vivo anti-Helicobacter activities of Eryngium foetidum (Apiaceae), Bidens pilosa (Asteraceae), and Galinsoga ciliata (Asteraceae) against Helicobacter pylori. Biomed Res. Int. 2016, Article ID 2171032, 7 pages. [CrossRef]

116. Bursalığlu, E.O. Evaluation of antibacterial activity of Triticum monococcu seeds, Castanea sativa seeds and Begonia maculata leaves against several bacterial strains. Turk. J. Biodiv. 2020, 3, 9-14. 
117. Buyun, L.; Tkachenko, H.; Kurhaluk, N.; Góralczyk, A.; Tomin, V.; Osadowski, Z. Screening for antimicrobial activity of nine ethanolic extracts obtained from leaves of Begonia plant: A possible alternative in the treatment of infections caused by Citrobacter freundii. Agrobiodiv. Improv. Nutr. Health Life Q. 2019, 3, 312-322. Available online: https://agrobiodiversity.uniag.sk/scientificpapers/article/view/279 (accessed on 11 May 2020).

118. Ogundare, A.O.; Oladejo, B.O. Antibacterial activities of the leaf and bark extract of Persea americana. Am. J. Ethnom. 2014, 1, 64-71.

119. Tegegn, A.; Meseret, C.E.; Bekele, H. Evaluation of endod (Phytolacca dodecandra L.) extracts against Botrytis fabae, a causative agent of chocolate spot disease of Vicia faba. Cogent Food Agric. 2019, 1, 1686948. [CrossRef]

120. Kosgei, C.J.; Mwendia, C.M.; Matasyoh, J.C.; Ngoci, N.S. Phytochemical analysis, cytotoxicity activity and acaricidal activity of aqueous crude extract of Phytolacca dodecandra against larvae of Rhipicephalus appendiculatus. J. Pharm. Biol. Sci. 2017, 12, 54-58.

121. Jeff, B.I.; Mbayi, O.; Ngiala, B.G.; Kapepula, M.P.; Mulwahali, W.J.; Lengbiye, E.; Liyongo, I.G.; Ngunde, N.S.; Ngbolua, K. Phytochemical Analysis and Assessment of Antibacterial and Antioxidant Activities of Phytolacca dodecandra L. Herit Leaf Extracts (Phytolaccaceae). Int. J. Biomed. Eng. Clin. Sci. 2019, 5, 31-39.

122. Patra, J.K.; Kim, E.S.; Oh, K.; Kim, H.J.; Kim, Y.; Baek, K.H. Antibacterial effect of crude extract and metabolites of Phytolacca americana on pathogens responsible for periodontal inflammatory diseases and dental caries. BMC Complement. Altern. Med. 2014, 14, 343. [CrossRef]

123. Hernández, M.; Murace, M.; Ringuelet, J.; Petri, I.; Gallo, D.; Arambarri, A. Effect of aqueous and alcohol extracts of Phytolacca tetramera (Phytolaccaceae) leaves on colletotrichum gloeosporioides (ascomycota). Bol. Soc. Arg. Bot. 2013, 48, 201-209. [CrossRef]

124. Mostafa, H.A.M.; El-Bakry, A.A.; Eman, A.A. Evaluation of antibacterial activity of different plant parts of Rumex Vesicarius L. at early and late vegetative stages of growth. Int. J. Pharm. Pharm. Sci. 2012, 4, 426-435.

125. Humeera, N.; Kamili, A.N.; Bandh, S.A.; Lone, B.A.; Gousia, N. Antimicrobial and antioxidant activities of alcoholic extracts of Rumex dentatus L. Microb. Pathog. 2013, 57, 17-20. [CrossRef]

126. Mhalla, D.; Bouaziz, A.; Ennouri, K.; Chawech, R.; Smaoui, S.; Jarraya, R.; Tounsi, S.; Trigui, M. Antimicrobial activity and bioguided fractionation of Rumex tingitanus extracts for meat preservation. Meat Sci. 2017, 125, 22-29. [CrossRef]

127. Orbán-Gyapai, O.; Liktor-Busa, E.; Kúsz, N.; Stefkó, D.; Urbán, E.; Hohmann, J.; Vasas, A. Antibacterial screening of Rumex species native to the Carpathian Basin and bioactivity-guided isolation of compounds from Rumex aquaticus. Fitoterapia 2017, 118, 101-106. [CrossRef]

128. Ordoñez, A.A.L.; Gómez, J.D.; Cudmani, N.M.; Vattuone, M.A.; Isla, M.I. Antimicrobial activity of nine extracts of Sechium edule (Jacq.) Swartz. Microb. Ecol. Health Dis. 2003, 15, 33-39. [CrossRef]

129. Bari, M.A.; Islam, W.; Khan, A.R.; Mandal, A. Antibacterial and antifungal activity of Solanum torvum (Solanaceae). Int. J. Agric. Biol. 2010, 12, 386-390.

130. Doss, A.; Mohammed, M.H.; Dhanabalan, R. Antibacterial activity of tannins from the leaves of Solanum trilobatum Linn. Ind. J. Sci. Technol. 2009, 2, 41-43.

131. Holetz, F.B.; Pessini, G.L.; Sanches, N.R.; Cortez, D.A.G.; Nakamura, C.V.; Dias Filho, B.P. Screening of some plants used in the Brazilian folk medicine for the treatment of infectious diseases. Mem. Inst. Oswaldo Cruz 2002, 97, 1027-1031. [CrossRef]

132. Edziria, H.L.; Smachd, M.A.; Ammarc, S.; Mahjoubc, M.A.; Mighric, Z.; Aounia, M.; Mastourib, M. Antioxidant, antibacterial, and antiviral effects of Lactuca sativa extracts. Ind. Crop. Prod. 2011, 34, 1182-1185. [CrossRef]

133. Altemimi, A.; Lakhssassi, N.; Abu-Ghazaleh, A.; Lightfoot, D.A. Evaluation of the antimicrobial activities of ultrasonicated spinach leaf extracts using RAPD markers and electron microscopy. Arch. Microbiol. 2017, 199, 1417-1429. [CrossRef]

134. Vale, A.P.; Santos, J.; Melia, N.; Peixoto, V.; Brito, N.V.; Beatriz, M.; Oliveira, P. Phytochemical composition and antimicrobial properties of four varieties of Brassica oleracea sprouts. Food Control 2015, 55, 248-256. [CrossRef]

135. Rashed, K.N.; Ćirić, A.; Glamočlija, J.; Calhelha, R.C.; Ferreira, C.F.R.I.; Soković, M. Identification of the bioactive constituents and the antibacterial, antifungal and cytotoxic activities of different fractions from Cestrum nocturnum L. Jordan J. Biol. Sci. 2018, 11, 273-279. 
136. Punjabi, Y.S.; Khilnani, V.L.; Damle, P.N. The investigation of antibacterial activity of Cestrum nocturnum. Pharmacophore 2015, 6, 81-87.

137. Sharif, M.A.; Atiqur, R.; Yunus, A.; Sun, C.K. Inhibition of plant pathogens in vitro and in vivo with essential oil and organic extracts of Cestrum nocturnum L. Pest. Biochem. Physiol. 2010, 96, 86-92.

(C) 2020 by the authors. Licensee MDPI, Basel, Switzerland. This article is an open access article distributed under the terms and conditions of the Creative Commons Attribution (CC BY) license (http://creativecommons.org/licenses/by/4.0/). 